\title{
An examination of trends in the growing scientific literature on approaching wildlife with drones
}

\author{
Matthew Mo and Katarina Bonatakis
}

\begin{abstract}
Drones or unoccupied aerial vehicles are rapidly being used for a spectrum of applications, including replacing traditional occupied aircraft as a means of approaching wildlife from the air. Though less intrusive to wildlife than occupied aircraft, drones can still cause varying levels of disturbance. Policies and protocols to guide lowest-impact drone flights are most likely to succeed if considerations are derived from knowledge from scientific literature. This study examines trends in the scientific literature on using drones to approach wildlife between 2000 and 2020, specifically in relation to the publication types, scientific journals that works are published in, purposes of drone flights reported, taxa studied, and locations of studies. From 223 publications, we observed a large increase in relevant scientific literature, the majority of which were peer-reviewed articles published across 86 scientific journals. The largest proportion of peer-reviewed research articles related to aquatic mammals or aquatic birds and the use or trial of drone flights for conducting population surveys, animal detection, or investigations of animal responses to drone flights. The largest proportion of articles were studies conducted in North America and Australia. Since animal responses to drone flights vary among taxa, populations, and geographic locations, we encourage further growth in the volume of relevant scientific literature needed to inform policies and protocols for specific taxa and (or) locations, particularly where knowledge gaps exist.
\end{abstract}

Key words: anthropogenic impacts, conference proceedings, project reports, research studies, university dissertations, unoccupied aerial vehicles, UAV.

Résumé : Les drones ou les véhicules aériens sans pilote (UAV) sont de plus en plus utilisés pour un éventail d'applications, y compris en remplacement des avions pilotés traditionnels comme moyen d'approcher la faune depuis les airs. Bien qu'ils soient moins intrusifs pour la faune que les avions pilotés, les drones peuvent tout de même causer divers niveaux de perturbation. Les politiques et les protocoles visant à guider les vols de drones afin d'avoir le moins d'impact sont les plus susceptibles de réussir si des considérations sont tirées des connaissances puisées de la littérature scientifique. Cette étude examine les tendances dans la littérature scientifique sur l'utilisation de drones pour approcher la faune entre 2000 et 2020, en particulier en ce qui concerne le type de publications et de revues scientifiques dans lesquels les travaux sont publiés, les objectifs de vols de drones signalés, les taxons étudiés et les lieux d'études. De 223 publications, les auteurs ont observé une forte augmentation de la littérature scientifique pertinente, dont la majorité étaient des articles évalués par des pairs et publiés dans 86 revues scientifiques. La plus grande proportion d'articles

Received 3 March 2021. Accepted 8 January 2022.

M. Mo. Department of Planning, Industry and Environment, Saving our Species program, Biodiversity, Conservation and Science, Parramatta, NSW 2150, Australia.

K. Bonatakis. University of Canberra, Bruce, ACT 2617, Australia.

Corresponding author: Matthew Mo (e-mail: matthew.mo@environment.nsw.gov.au).

(C) 2022 The Author(s). This work is licensed under a Creative Commons Attribution 4.0 International License (CC BY 4.0), which permits unrestricted use, distribution, and reproduction in any medium, provided the original author(s) and source are credited. 
de recherche examinés par des pairs portait sur les mammifères aquatiques ou les oiseaux aquatiques, et l'utilisation ou l'essai de vols de drones pour effectuer des relevés de population, la détection d'animaux ou des études sur les réponses des animaux aux vols de drones. La plus grande partie des articles étaient des études menées en Amérique du Nord et en Australie. Étant donné que les réactions des animaux aux vols de drones varient selon les taxons, les populations et les emplacements géographiques, les auteurs prônent la croissance du volume de documentation scientifique pertinente nécessaire pour éclairer les politiques et les protocoles pour des taxons ou des emplacements précis, en particulier lorsqu'il existe des lacunes dans les connaissances. [Traduit par la Rédaction]

Mots-clés : incidences anthropiques, travaux de congrès, comptes rendus de projets, projets de recherche, mémoires universitaires, véhicules aériens sans pilote, UAV.

\section{Introduction}

In wildlife management and research, drones or unoccupied aerial vehicles are rapidly replacing traditional occupied aircraft as a means of approaching wildlife to undertake detection, population counts, and aerial observations (Anderson and Galston 2013). Drone use is preferred over occupied aircraft in terms of being compact, cheaper to operate, easy to deploy, and therefore less time-consuming and requiring fewer qualifications and skills to operate (Aniceto et al. 2018; Koh and Wich 2012). Being unoccupied also means that collisions are substantially less of a human safety issue (Chabot and Bird 2015) since collisions involving occupied aircraft were a leading cause of work-related deaths in wildlife biologists (Sasse 2003). Drones have also been purported to be less intrusive to wildlife than occupied aircraft owing to their smaller size and lower noise emissions (Chabot and Bird 2012; Sardà-Palomera et al. 2012). However, these characteristics also mean that drone pilots may attempt to approach wildlife at closer distances than within occupied aircraft (Mo and Bonatakis 2022).

Anthropogenic disturbances have the potential to cause animals to sustain physiological stress, expend energy escaping, or abandon their offspring temporarily or permanently (Frid and Dill 2002; Houston et al. 2012). These impacts may subsequently have population-level impacts or affect local distributions of species if disturbances occur over broad expanses of time and space (Marion et al. 2020). Observable impacts on animal behaviour have been documented from both civilian (Rebolo-Ifrán et al. 2019) and professional drone flights (Wallace et al. 2018). There is therefore a need for government agencies to develop regulatory frameworks to manage risks associated with the increasing use of drones (Clarke and Moses 2014). This sentiment has been expressed in terms of drone impacts on public safety, privacy, and security (Reid 2014; Rao et al. 2016), as well as for minimising impacts on wildlife (Rebolo-Ifrán et al. 2019).

There is a growing body of scientific literature considering the effects of drone flights on different vertebrate taxa as well as reviews synthesising this information (Christie et al. 2016; Colefax et al. 2018). Scientific literature to date has shown numerous factors that influence animal responses to drone flights (Mo and Bonatakis 2022), which include drone characteristics such as their shape (McEvoy et al. 2016), size (McIntosh et al. 2018), colour and patterning (Mapes et al. 2020), and noise emissions (Weston et al. 2020). Flight practices are also important considerations, such as take-off distances from animals (Bech-Hansen et al. 2020), approach distances (Mustafa et al. 2018), angles of approach (Weimerskirch et al. 2018), and airspeed (Schroeder et al. 2020). Managers seeking to develop policies and protocols to guide lowest-impact drone flights are most likely to succeed if considerations are derived from knowledge of the above factors. However, effects of drone flights vary among taxa, populations, and geographic locations (Bennitt et al. 2019; Jarrett et al. 2020), 
and managers may find deficiencies in information relating to specific taxa and locations of their concern.

In this study, we examine trends in the scientific literature on using drones to approach wildlife. Specifically, we examine trends in (i) publication types, (ii) scientific journals that publish peer-reviewed articles, (iii) purposes of the drone flights, (iv) taxa studied, and $(v)$ locations of studies. We limited our review to relevant publications between 2000 and 2020.

\section{Methods}

Scientific literature was searched using Google Scholar, Web of Science, and Scopus databases for publications describing or providing commentary of practices involving drones approaching wildlife from 2000 to 2020 . Keywords used in the search were combinations of "drone", "unoccupied aerial vehicle", "unoccupied aerial system", "unmanned aerial vehicle", "unmanned aerial system", "remotely-piloted aircraft system", "unoccupied aircraft", "unmanned aircraft", "UAV", "UAS", and "RPAS" with "wildlife”, "animals", "birds", “mammals", "reptiles", “amphibians", "fish”, and "vertebrate”. Additional publications were sourced by querying relevant citations in other publications. This study concerned drone flights approaching animals; therefore, publications were excluded if drones were solely used for aerial radiotelemetry or locating indirect signs of wildlife such as nests.

Publications from the literature search were examined by their type (articles in peer-reviewed journals (research articles, review articles, commentary articles), conference proceedings, university dissertations, project reports), and year of publication. Articles published in peer-reviewed journals were examined by journal. Research articles in peer-reviewed journals were examined for their main purposes for using drones (e.g., using or trialling drones for animal detection or investigating animal responses to drone flights), specific taxa, and the country the fieldwork was undertaken in.

\section{Results}

The literature search found 223 publications that described or provided commentary involving flight practices of drones approaching wildlife between 2000 and 2020 (see Table A1).

\section{Types of publications}

Articles in peer-reviewed journals comprised the largest proportion of publications from the literature search, the majority of them research articles $(n=169)$ as well as 22 review articles and four commentary articles (Fig. 1a). Seven of the review articles concerned specific taxa, all of which were aquatic animals (Smith et al. 2016; Borrelle and Fletcher 2017; Fiori et al. 2017; Mustafa et al., 2018; Rees et al. 2018; Schofield et al. 2019; Raoult et al. 2020). There were also 10 conference proceedings, 10 university dissertations, and eight project reports.

More than $85 \%$ of publications were published between 2015 and 2020 (Fig. 1b). The earliest publication was a university dissertation completed in 2003 (Jones 2003). The majority of other university dissertations found in the literature search were completed from 2016 onwards. The earliest conference proceedings from the literature search were published in 2011 (Israel 2011; Selby et al. 2011), with subsequent conference proceedings published every year to second year. 
Fig. 1. (a) Publication types describing or providing commentary of flight practices of drones approaching wildlife $(n=223)$. (b) Temporal distribution of articles in peer-reviewed journals comprise of research, review and commentary articles represented in (a).

(a)

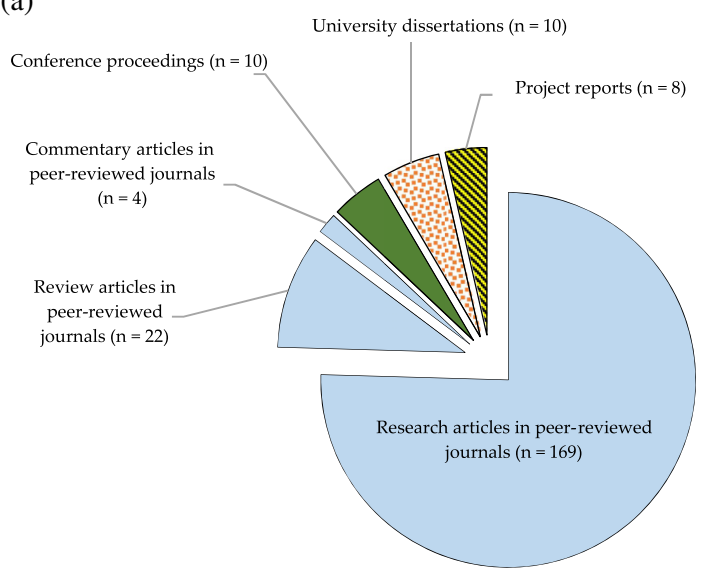

(b)

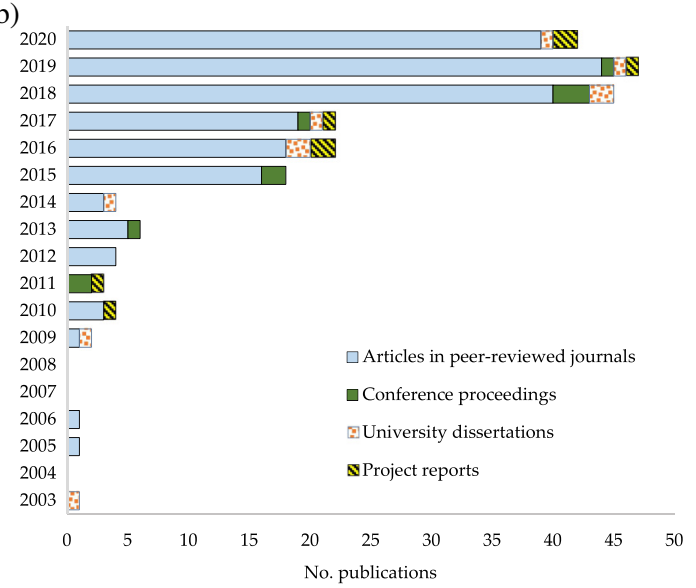

Scientific journals

Peer-reviewed articles were published across 86 scientific journals, 63 of which published only one article (Table 1). The highest number of articles were published in the Journal of Unmanned Vehicle Systems $(n=22$; renamed to Drone Systems and Applications in 2022), PLoS ONE ( $n=15)$, Drones $(n=14)$, Scientific Reports $(n=9)$, Polar Biology $(n=8)$, Biological Conservation $(n=6)$, and Frontiers in Marine Science $(n=6)$. Articles appearing in these seven journals were first published in 2012 (Fig. 2). The Journal of Unmanned Vehicle Systems, established in 2013, published eight articles in 2015 and has maintained publication of two to four articles in each subsequent year. PLOS ONE, established in 2006, has steadily published between one to three articles in most years since 2012. Drones, established in 2017, published two to six articles annually from 2018 to 2020.

\section{Taxa}

Of the 169 peer-reviewed research articles from the literature search, all but one (Erbe et al. 2017) concerned specific taxa (Fig. 3). A large proportion of these articles concerned mammals $(n=94)$, in particular aquatic mammals $(n=53)$. The few articles concerning sirenians were some of the earliest articles concerning aquatic mammals. Articles concerning cetaceans and pinnipeds were first published in 2009 and 2013, respectively, and increasingly published between 2015 and 2020 (Fig. 4a). There was only one article concerning hippopotamuses, which was published in 2019 (Inman et al. 2019).

Nonaquatic mammals were represented in 42 peer-reviewed research articles. Articles concerning terrestrial ungulates $(n=17)$ and carnivorans $(n=11)$ were particularly prominent, first appearing in peer-reviewed literature in 2012 (Koh and Wich 2012) and 2013 (Koski et al. 2013), respectively (Fig. 4b). Articles concerning primates were distributed between 2012 and 2020, increasingly published more recently. Similarly, articles concerning nonaquatic carnivorans and marsupials were increasingly published in the more recent years. The three articles concerning elephants were distributed between 2013 and 2019 (Vermeulen et al. 2013; Hahn et al. 2017; Bennitt et al. 2019).

Birds were also represented in a large proportion of research articles $(n=67)$. Between 2005 and 2012, these articles exclusively concerned aquatic birds, which included waterfowl, waders, penguins, and other seabirds (Fig. $4 c)$. Aquatic birds $(n=53)$ continued to be 
Table 1. Scientific journals identified in the literature search that published only one article describing or providing commentary of flight practices of drones approaching wildlife.

\begin{tabular}{ll}
\hline Journal title & \\
\hline Acta Theriologica Sinica & IOP Conference Series: Earth and Environmental \\
Animal Conservation & Science \\
Animals & Journal of Applied Ecology \\
Annual Review of Marine Science & Journal of Ecology and Environment \\
Aquatic Conservation: Marine and Freshwater & Journal of Ecotourism \\
Ecosystems & Journal of Environmental Planning and \\
Aquatic Mammals & Management \\
Ardea & Journal of Ethology \\
Australian Field Ornithology & Journal of Fish Biology \\
Australian Mammalogy & Journal of Neuroscience Methods \\
Australian Zoologist & Journal of the Japanese Society of Agricultural \\
Biodiversity Observations & Machinery and Food Engineers \\
Biology Letters & Journal of Wildlife Management \\
Bird Conservation International & Latin American Journal of Aquatic Research \\
Bird Study & Mammal Research \\
Bollettino del Museo di Storia Naturale di Venezia & Marine Pollution Bulletin \\
CCAMLR Science & Marine Turtle Newsletter \\
Conservation Physiology & mSystems \\
Crop Protection & Ocean and Coastal Management \\
Current Zoology & Paladyn, Journal of Behavioral Robotics \\
Ecological Applications & Raptors Conservation \\
Ecological Informatics & Remote Sensing in Ecology and Conservation \\
Endangered Species Research & Royal Society Open Science \\
Environmental Conservation & Surveying and Land Information Science \\
Environmental Practice & The Auk \\
Folia Primatologica & Tropical Conservation Science \\
Food Webs & Unmanned Systems \\
Functional Ecology & Viruses \\
Global Ecology and Conservation & Waterbirds \\
Herpetological Review & Wetlands Ecology and Management \\
bis & Wildlife Biology \\
ICES Journal of Marine Science & Wildlife Research \\
Integrative Zoology & \\
International Journal of Environmental Research and Public Health & \\
\hline & \\
\hline & \\
\hline
\end{tabular}

the most represented bird taxa in articles from 2013 to 2020. Articles concerning birds of prey were distributed between 2013 and 2018. Articles concerning passerines and galliforms were first published in the scientific literature in 2015 (Weissensteiner et al. 2015) and 2016 (Scobie and Hugenholtz 2016), respectively. In 2020, articles concerning parrots, pigeons (Weston et al. 2020), and swifts (Mesquita et al. 2020) also appeared in peer-reviewed literature.

Reptiles were represented in 15 research articles, all of which concerned aquatic taxa (Fig. $4 d$ ). The earliest articles concerning crocodilians were research studies published in 2006 and 2012 that trialled drone techniques on a selection of varied taxa (Jones 2003; Martin et al. 2012). More recent articles concerning crocodilians have been ecological or behavioural studies of crocodilian species incorporating drone flights (Bevan et al. 2018; Ezat et al. 2018; Gallagher et al. 2018; Thapa et al. 2018). The earliest article concerning sea turtles was published in 2015 (Bevan et al. 2015), which has been accompanied by one to two additional articles each year from 2016 to 2020.

Fish were represented in 17 research articles, the majority of which concerned elasmobranchs $(n=15)$. Three articles involved detections of bony fishes through drone flights (Colefax et al. 2019; Jech et al. 2020; Kelaher et al. 2020). 
Fig. 2. Temporal distribution of peer-reviewed articles published in seven scientific journals $(n=80)$.

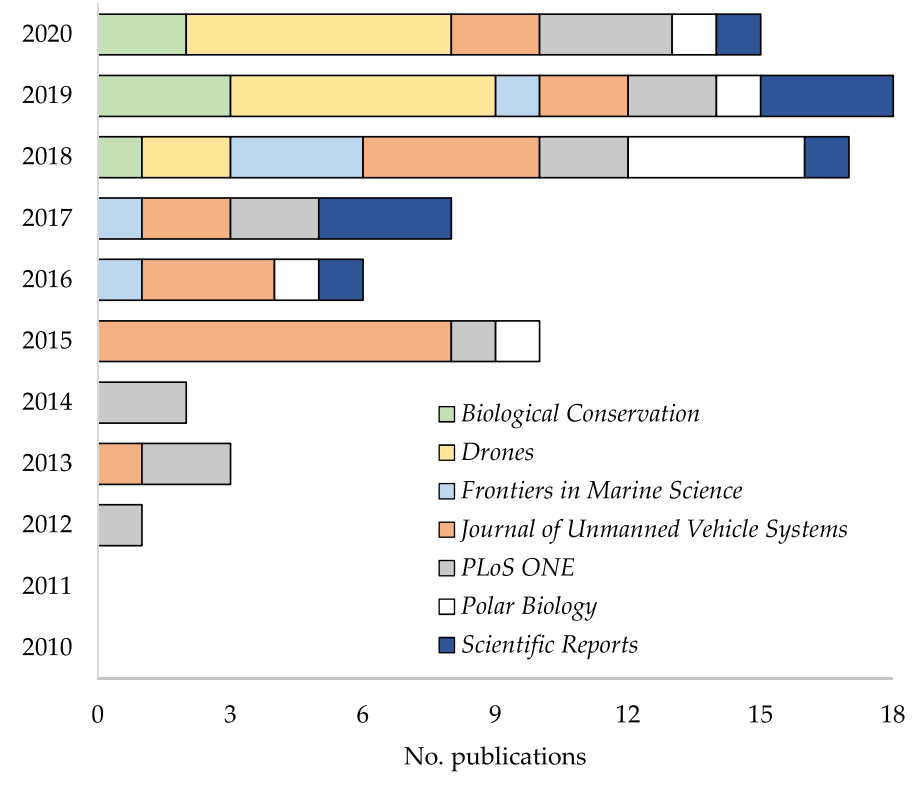

Fig. 3. Broad taxonomical classifications represented in peer-reviewed research articles $(n=169)$. Note that some research studies were conducted across more than one taxon.

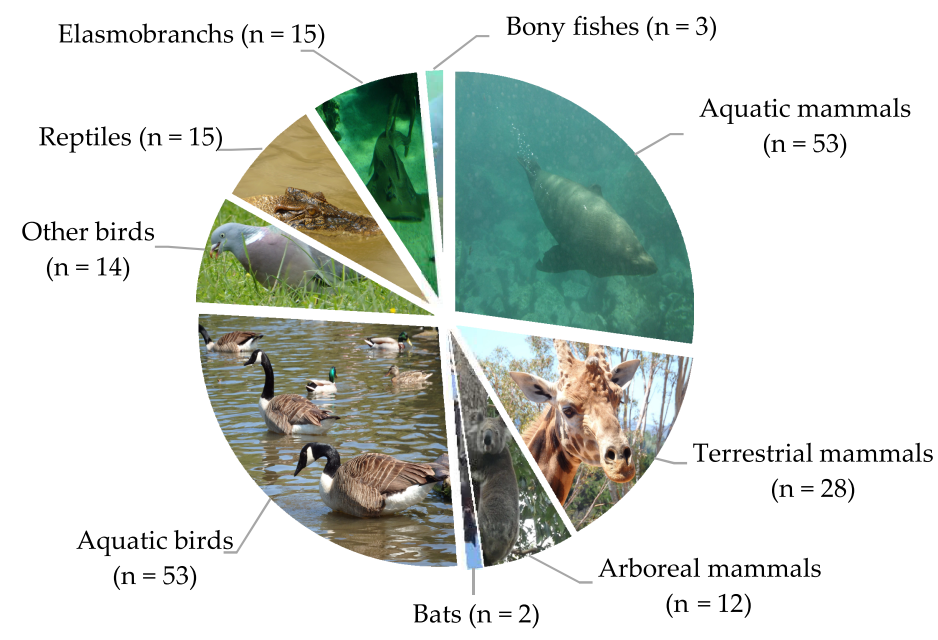

\section{Purposes of drone flights}

The main purposes of the 169 peer-reviewed research articles were examined, some of which had more than one main purpose. Large proportions of these articles related to the use or trial of drone flights to conduct population surveys $(n=52)$, undertake animal detection $(n=50)$, or conduct investigations of animal responses to drone flights $(n=40)$. Animal detection and population surveys through drone flights appear in the scientific literature as early as 2005 and 2010, respectively, progressively increasing in the volume of 
Fig. 4. Taxonomical classifications of animals represented in peer-reviewed research articles: $(a)$ aquatic mammals $(n=52),(b)$ nonaquatic mammals $(n=43),(c)$ birds $(n=64)$, and $(d)$ reptiles $(n=15)$.

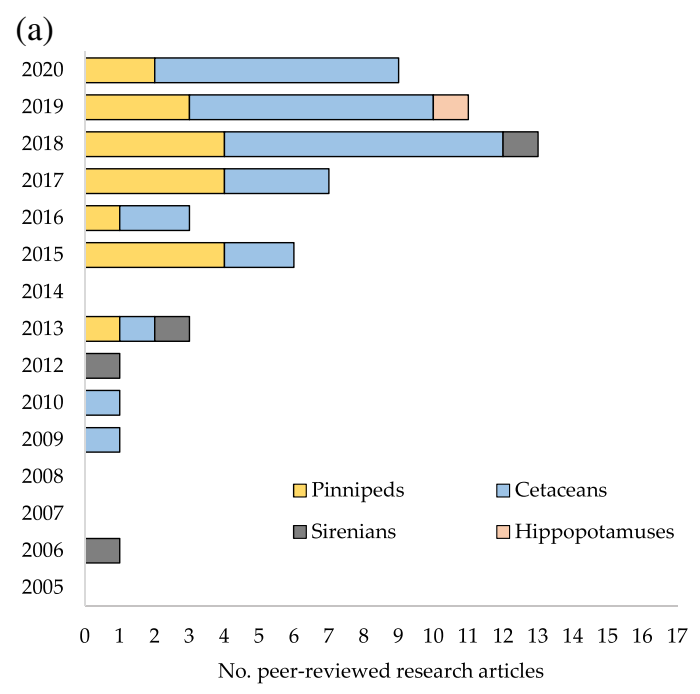

(c)

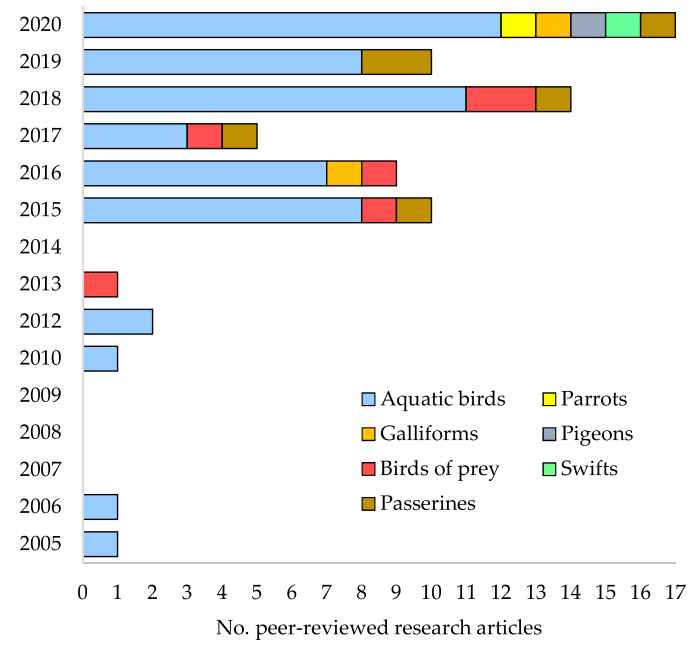

(b)

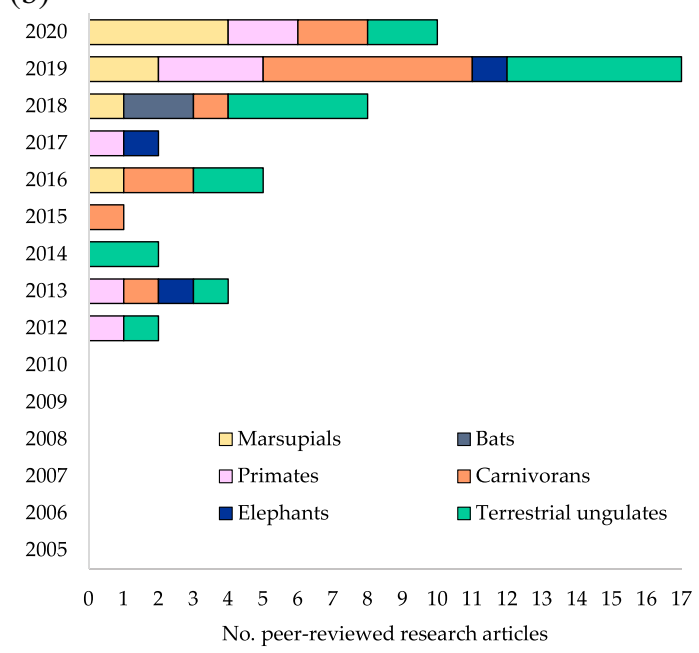

(d)

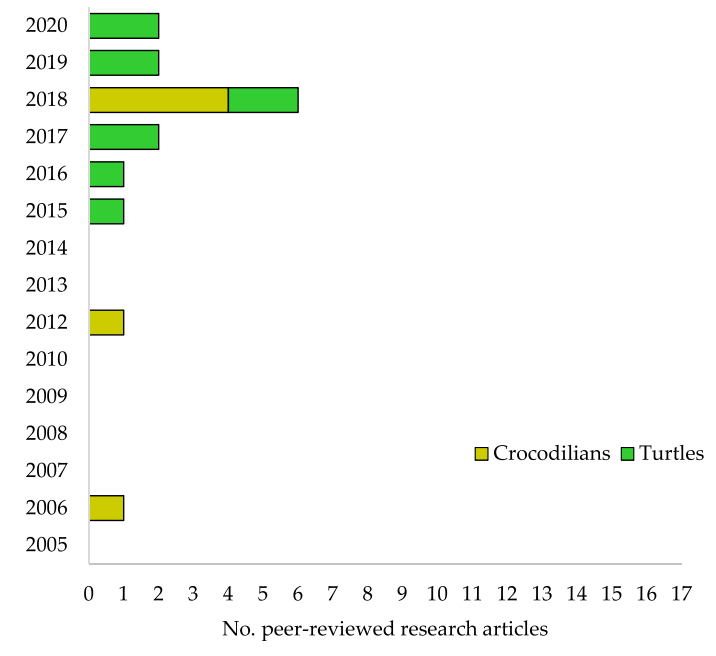

research articles (Fig. 5). Research articles on investigations of animal responses to drone flights have been published since 2015.

We found 12 research articles related to using drones to observe natural animal behaviour, mostly from 2018 onwards. All but one of these research articles (Inoue et al. 2019) concerned aquatic taxa (Raoult et al. 2018; Adams et al. 2020) such as elasmobranchs (Lea et al. 2018; Rieucau et al. 2018; Tucker et al. 2019; Dines et al. 2020; Frixione et al. 2020; Porter et al. 2020), crocodilians (Gallagher et al. 2018), turtles (Bevan et al. 2016), and cetaceans (Torres et al. 2018).

In 17 research articles, drone flights were used to collect biological data, which were body condition in pinnipeds (Allan et al. 2019; Hodgson et al. 2020) and cetaceans (Christiansen et al. 2016; Krause et al. 2017); individual markings (Durban et al. 2015) and biochemical vital signs in cetaceans (Horton et al. 2019); morphometric measurements in 
Fig. 5. Temporal distribution of peer-reviewed research articles in which drone flights were used for different purposes $(n=170)$.

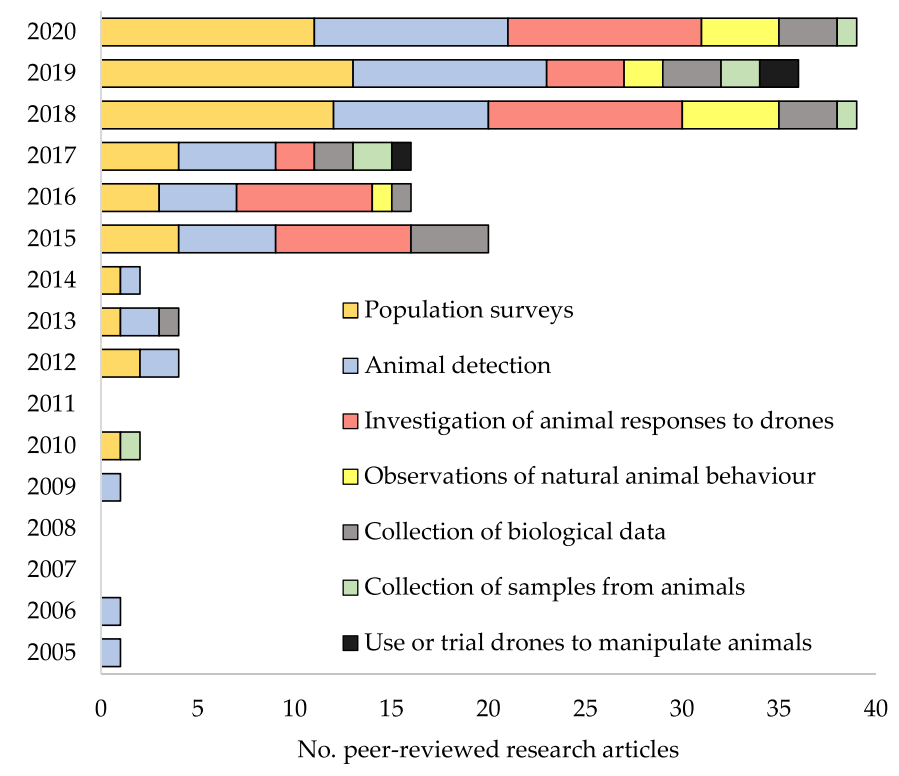

pinnipeds (Pomeroy et al. 2015), cetaceans (Christiansen et al. 2018, 2019), and bony fishes (Jech et al. 2020); vocalisations in bats (Fu et al. 2018; Kloepper and Kinniry 2018); and nest contents and survival in birds of prey (Potapov et al. 2013; Junda et al. 2015), aquatic birds (Sardà-Palomera et al. 2017; Lachman et al., 2020), and passerines (Weissensteiner et al. 2015). A further seven research articles involved drone flights to collect samples from animals, which all related to blow sampling from cetaceans (Acevedo-Whitehouse et al. 2010; Apprill et al. 2017; Pirotta et al. 2017; Geoghegan et al. 2018; Nelson et al. 2019; Raudino et al. 2019; Centelleghe et al. 2020).

Only three research articles involved drone flights conducted to deliberately disturb and disperse animals from certain areas. These publications concerned agricultural crop protection from elephants (Hahn et al. 2017) and passerines (Nakajima et al. 2019; Wandrie et al. 2019).

\section{Research locations}

The largest proportion of peer-reviewed research articles were studies conducted in North America $(n=64)$ (Fig. 6). These studies were conducted across 10 countries, particularly in the United States of America ( $n=25$, with an additional 7 in Alaska) (Fig. 7a). Studies in the United States of America were published as early as 2005 (Abd-Elrahman et al. 2005) and up to eight were published annually between 2015 and 2020. The earliest studies in Mexico $(n=8)$ and Canada were published in 2010 (Acevedo-Whitehouse et al. 2010) and 2012 (Chabot and Bird 2012), respectively; however, the majority were published between 2015 and 2019. North American studies published in research articles were also conducted in Costa Rica (Sykora-Bodie et al. 2017; Gray et al. 2019), Greenland (Bröker et al. 2019; Lee et al. 2019), Belize (Ramos et al. 2018), Panama (Kays et al. 2019), the Bahamas (Hensel et al. 2018) and Guatemala (Warembourg et al. 2020). 
Fig. 6. Continents represented in peer-reviewed research articles $(n=169)$. Note that some research studies were conducted across more than one continent.

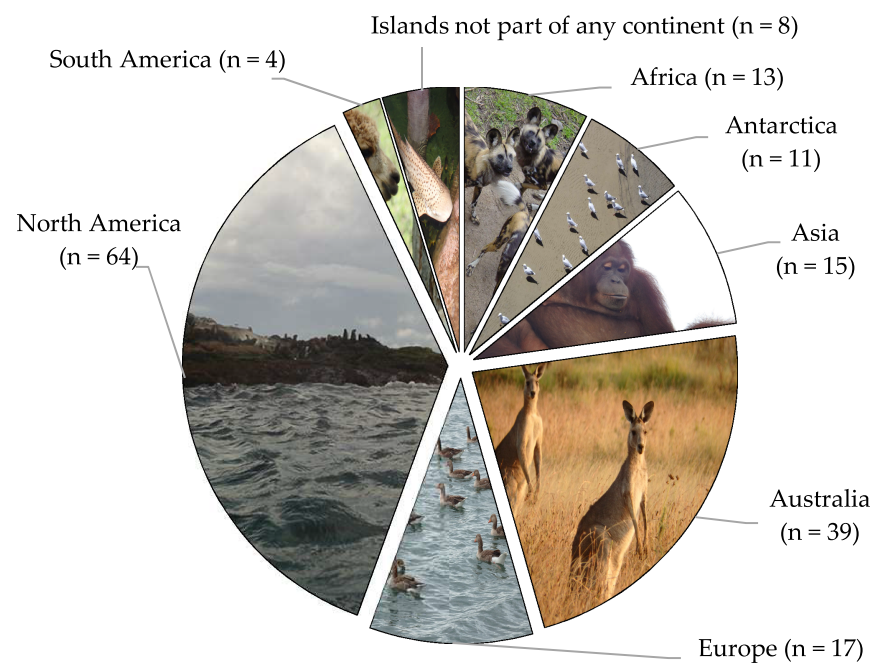

Fig. 7. Temporal distribution of peer-reviewed research articles conducted in $(a)$ North America $(n=64)$, and (b) Australia $(n=39)$. Note that some research studies were conducted across more than one country.

(a)

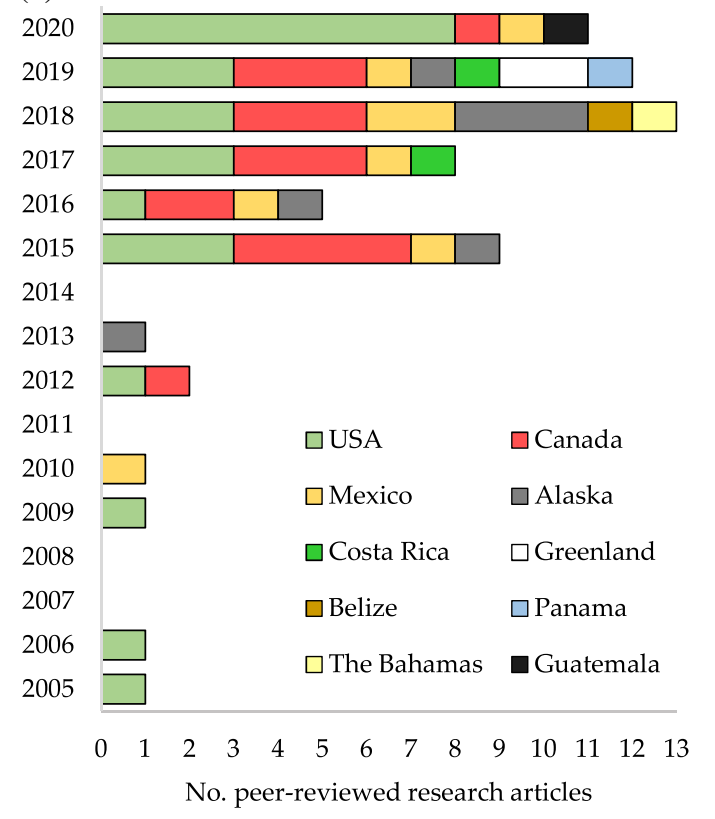

(b)

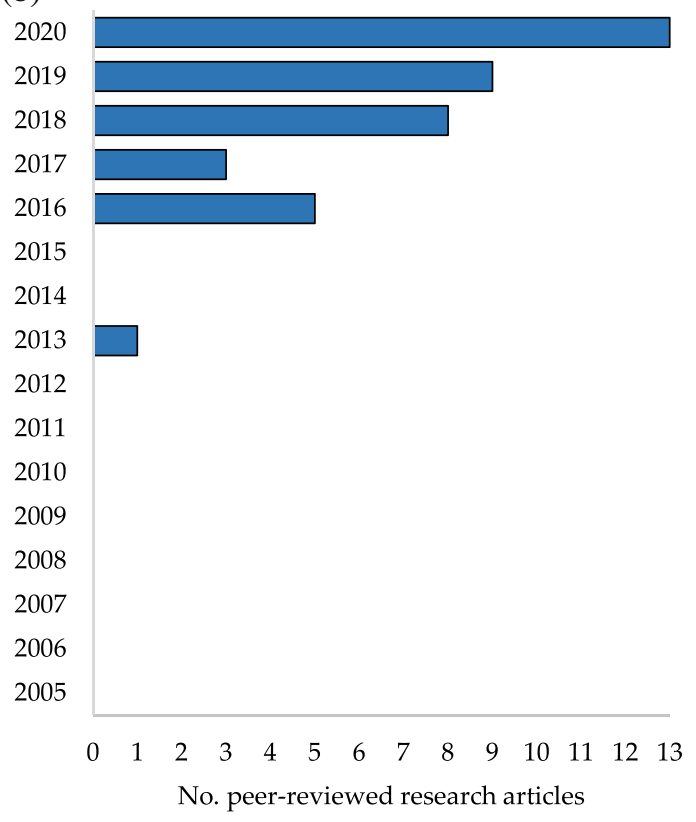

The second largest proportion of research articles were studies conducted in Australia $(n=39)$. The earliest Australian article was published in 2013 (Hodgson et al. 2013) and subsequent articles were published between 2016 and 2020 (Fig. 7b). 
Table 2. Temporal distribution of peer-reviewed research articles of studies conducted in European countries.

\begin{tabular}{|c|c|c|c|c|c|c|c|}
\hline Country & 2012 & 2014 & 2015 & 2017 & 2018 & 2019 & 2020 \\
\hline Italy & - & - & - & - & Valle and Scarton (2018) & $\begin{array}{l}\text { Valle and } \\
\text { Scarton (2019) }\end{array}$ & $\begin{array}{l}\text { Centelleghe et al. (2020); } \\
\text { Valle and Scarton (2020) }\end{array}$ \\
\hline Spain & $\begin{array}{l}\text { Sardà- } \\
\quad \text { Palomera } \\
\text { et al. (2012) }\end{array}$ & $\begin{array}{l}\text { Barasona } \\
\quad \text { et al. (2014) }\end{array}$ & - & $\begin{array}{l}\text { Sardà- } \\
\quad \text { Palomera } \\
\text { et al. (2017) }\end{array}$ & Afán et al. (2018) & - & - \\
\hline England & - & - & $\begin{array}{l}\text { Pomeroy } \\
\text { et al. (2015) }\end{array}$ & - & Rush et al. (2018) & - & - \\
\hline Greece & - & - & - & $\begin{array}{l}\text { Schofield } \\
\text { et al. (2017) }\end{array}$ & - & - & Centelleghe et al. (2020) \\
\hline Denmark & - & - & - & - & - & - & Bech-Hansen et al. 2020 \\
\hline France & - & - & Vas et al. (2015) & - & - & - & - \\
\hline Poland & - & - & - & - & Witczuk et al. (2018) & - & - \\
\hline Portugal & - & - & - & - & - & Inoue et al. (2019) & - \\
\hline Scotland & - & - & - & - & - & - & Jarrett et al. (2020) \\
\hline Sweden & - & - & $\begin{array}{l}\text { Weissensteiner } \\
\text { et al. (2015) }\end{array}$ & - & - & - & - \\
\hline
\end{tabular}


Seventeen research articles were studies conducted in Europe (Fig. 6), distributed across 10 countries (Table 2). The earliest European articles were two studies conducted in Spain, published in 2012 and 2014. The largest proportion of European articles were studies conducted in Italy $(n=4)$ and Spain $(n=4)$, mostly between 2018 and 2020.

Fifteen research articles were studies conducted in Asia (Fig. 6), distributed across seven countries. The earliest Asian articles were studies conducted in Indonesia and Russia, published in 2012 and 2013, respectively (Table 3). The largest proportion of Asian articles were studies conducted in China $(n=5)$, Indonesia $(n=3)$, and South Korea $(n=3)$, mostly published between 2017 and 2019.

Eleven research articles were studies conducted in Antarctica (Fig. 6). The earliest of these articles was published in 2010 (Table 4). The remainder were published between 2015 and 2020, with one to two of these articles published each year within this period.

Thirteen research articles were studies conducted in Africa (Fig. 6). These studies were distributed across eight identified countries, two of them island countries east of the mainland. Each country was only represented in one article, except for Botswana $(n=3)$ and South Africa $(n=3)$. The earliest African articles were studies conducted in Burkina Faso and South Africa, published in 2013 and 2014, respectively (Table 5).

Only four articles were studies conducted in South America (Fig. 6), two in Brazil (Mesquita et al. 2020; Oliveira-da-Costa et al. 2020) and two in Argentina (Christiansen et al. 2019; Schroeder et al. 2020).

Eight research articles were studies conducted in six island countries that are not part of any continent (Fig. 6). These articles were all published between 2015 and 2019 (Table 6). Studies conducted in French Polynesia and New Zealand comprised half of these eight articles.

\section{Discussion}

The volume of scientific literature relating to approaching wildlife with drones had exponentially increased between 2003 and 2020, particularly in the last five years. This reflects the growing popularity of drones and how they will likely be increasingly used and readily adopted for a spectrum of applications (Anderson and Gaston 2013). The largest proportion of peer-reviewed articles were concerning drone-based population surveys as an alternative to traditional methods using occupied aircraft (Chabot and Bird 2015; Borrelle and Fletcher 2017). Drones have subsequently appeared in the scientific literature as a means of undertaking aerial animal detection and more recently extended to innovative techniques for observing natural animal behaviours, collecting biological data, and even collecting samples from animals or deliberately disturbing animals from agricultural areas. However, our review found that population surveys and animal detection have consistently remained the predominant drone applications amongst newer innovations.

Outside of wildlife management and research, drones are also increasingly being adopted in a wide range of applications such as land surveillance (Tripicchio et al. 2015), traffic monitoring (Coifman et al. 2006), disaster management (Restas 2015), agricultural practices (Frankelius et al. 2019), defence and law enforcement (Reid 2014; Floreano and Wood 2014), and cinematography (Cheng 2015). Drones are also available as off-the-shelf products and are used for civilian activities by recreationalists (Siyuan 2015). The expansion in drone applications notionally increases the chances of wildlife coming into contact with drones. This raises the importance of managers developing adequate regulatory frameworks to minimise risks (Weston et al. 2020). In particular, the uptake of commercially available drones for civilian recreation poses the potential for a wide array of medium- to large-bodied animals to come into contact with drones beyond the taxa traditionally monitored by aerial surveys. The significant increase in relevant scientific literature therefore 
Table 3. Temporal distribution of peer-reviewed research articles of studies conducted in Asian countries.

\begin{tabular}{|c|c|c|c|c|c|c|c|}
\hline Country & 2012 & 2013 & 2015 & 2017 & 2018 & 2019 & 2020 \\
\hline China & - & - & - & - & $\begin{array}{l}\text { Guo et al. (2018); } \\
\text { Su et al. (2018) }\end{array}$ & $\begin{array}{l}\text { Wu et al. (2019); } \\
\text { Yang et al. (2019) }\end{array}$ & He et al. (2020) \\
\hline Indonesia & $\begin{array}{l}\text { Koh and } \\
\text { Wich (2012) }\end{array}$ & - & - & $\begin{array}{l}\text { Radiansyah } \\
\text { et al. (2017) }\end{array}$ & - & Burke et al. (2019) & - \\
\hline South Korea & - & - & - & Han et al. (2017) & - & $\begin{array}{l}\text { Hong et al. (2019); } \\
\text { Lee et al. (2019) }\end{array}$ & - \\
\hline Japan & - & - & - & - & & Nakajima et al. (2019) & - \\
\hline Nepal & - & - & - & - & Thapa et al. (2018) & - & - \\
\hline Russia & - & $\begin{array}{l}\text { Potapov } \\
\text { et al. (2013) }\end{array}$ & - & - & - & - & - \\
\hline Taiwan & - & - & $\begin{array}{l}\text { Liu } \\
\text { et al. (2015) }\end{array}$ & - & - & - & - \\
\hline
\end{tabular}


Table 4. Temporal distribution of peer-reviewed research articles of studies conducted in Antarctica.

\begin{tabular}{lll}
\hline Year & $\begin{array}{l}\text { No. } \\
\text { articles }\end{array}$ & References \\
\hline 2010 & 1 & Gardner et al. (2010) \\
2015 & 1 & Goebel et al. (2015) \\
2016 & 2 & Korczak-Abshire et al. (2016); Rümmler et al. (2016) \\
2017 & 1 & Krause et al. (2017) \\
2018 & 2 & Rümmler et al. (2018); Zmarz et al. (2018) \\
2019 & 2 & Korczak-Abshire et al. (2019); Pfeifer et al. (2019) \\
2020 & 2 & Bird et al. (2020); Oosthuizen et al. (2020) \\
\hline
\end{tabular}

provides a valuable evidence base to managers to leverage from in developing policies and protocols to guide lowest-impact drone flights. This growing body of knowledge helps to inform principles and considerations that policies and protocols should consider, such as incorporating specific drone systems and flight practices to minimise disturbance (Mo and Bonatakis 2022).

A range of studies highlight substantial variations in animal responses to drone flights among taxa, populations, and geographic locations (Mulero-Pázmány et al. 2014; Jarrett et al. 2020). This presents a challenge for developing intuitive policies and protocols, which means that managers will often require taxa- and (or) location-specific literature. Our review found substantial variation in the volume of scientific literature between vertebrate taxa and continents. The scientific capacity of countries within the range of different species is a likely variable influencing these disparities, as well as the body mass and threat status of different species (dos Santos et al. 2020). Amongst peer-reviewed articles involving drone approaches of wildlife, aquatic mammals and aquatic birds were the most studied taxa, which corresponds with these taxa having been historically monitored through aerial surveys (Angliss et al. 2018; Colefax et al. 2018; Wang et al. 2019). In contrast, there were notable deficiencies such as an absence of studies on taxonomical groups that could potentially be susceptible to drone-induced disturbances such as rodents, xenarthrans, and lizards. Furthermore, there are few relevant studies on diverse taxonomical groups such as bats, marsupials, passerines, and other birds. We therefore encourage future studies investigating animal responses to drone flights for underrepresented taxonomical groups.

Based on trends observed in this review, we project that the volume of scientific literature on drone applications for wildlife research and management will likely continue to grow substantially in the near future. The majority of scientific literature identified in our review was published in peer-reviewed journals, which provides a level of quality control and confidence in managers deriving implications from research findings (Sizo et al. 2019). The requirement of certain university degrees to undertake research projects presents a convenient pathway for accelerating research (Schopfel et al. 2014), and some of the dissertations we found were subsequently also published in peer-reviewed journals (e.g., Chabot 2009; Chabot and Bird 2012). We found that peer-reviewed articles were published across a broad range of scientific journals, most frequently in two focused journals, the Journal of Unmanned Vehicle Systems and Drones, both of which were established relatively recently. The establishment of such focused journals reflects our projection of substantial growth in this research area. 
Table 5. Temporal distribution of peer-reviewed research articles of studies conducted in African countries.

\begin{tabular}{|c|c|c|c|c|c|c|c|}
\hline Country & 2013 & 2014 & 2016 & 2017 & 2018 & 2019 & 2020 \\
\hline Botswana & - & - & - & - & - & $\begin{array}{l}\text { Bennitt et al. (2019); } \\
\text { Inman et al. (2019) }\end{array}$ & Francis et al. (2020) \\
\hline South Africa & - & $\begin{array}{l}\text { Mulero-Pázmány } \\
\text { et al. (2014) }\end{array}$ & - & - & Ezat et al. (2018) & - & $\begin{array}{l}\text { Dines and } \\
\text { Gennari (2020) }\end{array}$ \\
\hline Burkina Faso & $\begin{array}{l}\text { Vermeulen } \\
\text { et al. (2013) }\end{array}$ & - & - & - & - & - & - \\
\hline Madagascar & - & - & - & - & - & - & Semel et al. (2020) \\
\hline Mozambique & - & - & Allport (2016) & - & - & - & - \\
\hline Namibia & - & - & - & - & Kellenberger et al. (2018) & - & - \\
\hline Seychelles & - & - & - & - & Lea et al. (2018) & - & - \\
\hline Tanzania & - & - & - & Hahn et al. (2017) & - & - & - \\
\hline Not specified & - & - & - & - & - & - & Haalck et al. (2020) \\
\hline
\end{tabular}


Table 6. Temporal distribution of peer-reviewed research articles of studies conducted in island countries not part of any continent.

\begin{tabular}{lllll}
\hline Country & 2015 & 2016 & 2018 & 2019 \\
\hline French Polynesia & - & Kiszka et al. (2016) & $\begin{array}{l}\text { Rieucau et al. (2018) } \\
\text { Geoday et al. (2018) }\end{array}$ & $\begin{array}{l}\text { Fettermann } \\
\text { et al. (2019) }\end{array}$ \\
New Zealand & - & - & - & Horton et al. (2019) \\
Cook Islands & - & - & - & - \\
Falkland Islands & $\begin{array}{c}\text { Ratcliffe } \\
\text { et al. (2015) }\end{array}$ & - & Weimerskirch & - \\
$\begin{array}{l}\text { French Southern } \\
\text { Territories }\end{array}$ & - & - & et al. (2018) & - \\
Tristan da Cunha & - & McClelland & - & \\
\hline
\end{tabular}

\section{Acknowledgements}

This work was undertaken as part of the New South Wales Government's Saving our Species program. Useful comments from two anonymous reviewers improved the manuscript.

\section{References}

Abd-Elrahman, A., Pearlstine, L., and Percival, F. 2005. Development of pattern recognition algorithm for automatic bird detection from unmanned aerial vehicle imagery. Surv. Land Inf. Sci. 65: 37.

Acevedo-Whitehouse, K., Rocha-Gosselin, A., and Gendron, D. 2010. A novel non-invasive tool for disease surveillance of free-ranging whales and its relevance to conservation programs. Anim. Conserv. 13: 217-225. doi: 10.1111/j.1469-1795.2009.00326.x.

Adams, K., Broad, A., Ruiz-García, D., and Davis, A.R. 2020. Continuous wildlife monitoring using blimps as an aerial platform: A case study observing marine megafauna. Aust. Zool. 40: 407-415. doi: 10.7882/AZ.2020.004.

Afán, I., Máñez, M., and Díaz-Delgado, R. 2018. Drone monitoring of breeding waterbird populations: the case of the glossy ibis. Drones, 2: 42. doi: 10.3390/drones2040042.

Allan, B.M., Ierodiaconou, D., Hoskins, A.J., and Arnould, J.P. 2019. A rapid UAV method for assessing body condition in fur seals. Drones, 3: 24. doi: 10.3390/drones3010024.

Allport, G. 2016. Fleeing by whimbrel Numenius phaeopus in response to a recreational drone in Maputo Bay, Mozambique. Biodivers. Obs. 7: 44.

Anderson, K., and Gaston, K.J. 2013. Lightweight unmanned aerial vehicles will revolutionize spatial ecology. Front. Ecol. Environ. 11: 138-146. doi: 10.1890/120150.

Angliss, R.P., Hall, F.P., Kennedy, A., and Sformo, T. 2018. Comparing manned to unmanned aerial surveys for cetacean monitoring in the Arctic: Methods and operational results. J. Unmanned Veh. Syst. 6: 109-127. doi: 10.1139/ juvs-2018-0001.

Aniceto, A.S., Biuw, M., Lindstrøm, U., Solbø, S.A., Broms, F., and Carroll, J. 2018. Monitoring marine mammals using unmanned aerial vehicles: quantifying detection certainty. Ecosphere, 9: e02122. doi: 10.1002/ecs2.2122.

Apprill, A., Miller, C.A., Moore, M.J., Durban, J.W., Fearnbach, H., and Barrett-Lennard, L.G. 2017. Extensive core microbiome in drone-captured whale blow supports a framework for health monitoring. mSystems, 2: e00119-e00117. doi: 10.1128/mSystems.00119-17. PMID: 29034331.

Barasona, J.A., Mulero-Pázmány, M., Acevedo, P., Negro, J.J., Torres, M.J., Gortázar, C., and Vicente, J. 2014. Unmanned aircraft systems for studying spatial abundance of ungulates: relevance to spatial epidemiology. PLoS ONE, 9: e115608. doi: 10.1371/journal.pone.0115608. PMID: 25551673.

Bech-Hansen, M., Kallehauge, R.M., Lauritzen, J.M.S., Sørensen, M.S., Laubek, B., Jensen, L.F., Petoldi, C., and Bruhn, D. 2020. Evaluation of disturbance effect on geese caused by an approaching unmanned aerial vehicle. Bird Conserv. Int. 30: 169-175. doi: 10.1017/S0959270919000364.

Bennitt, E., Bartlam-Brooks, H.L.A., Hubel, T.Y., and Wilson, A.M. 2019. Terrestrial mammalian wildlife responses to unmanned aerial systems approaches. Sci. Rep. 9: 2142. doi: 10.1038/s41598-019-38610-x. PMID: 30765800.

Bevan, E., Whiting, S., Tucker, T., Guinea, M., Raith, A., and Douglas, R. 2018. Measuring behavioral responses of sea turtles, saltwater crocodiles, and crested terns to drone disturbance to define ethical operating thresholds. PLoS ONE, 13: e0194460. doi: 10.1371/journal.pone.0194460. PMID: 29561901.

Bevan, E., Wibbels, T., Najera, B.M.Z., Martinez, M.A.C., Martinez, L.A.S., Martinez, F.I., et al. 2015. Unmanned aerial vehicles (UAVs) for monitoring sea turtles in near-shore waters. Mar. Turtle Newsl. 145: 19-22.

Bevan, E., Wibbels, T., Navarro, E., Rosas, M., Najera, B.M.Z., Sarti, L., et al. 2016. Using unmanned aerial vehicle (UAV) technology for locating, identifying, and monitoring courtship and mating behavior in the green turtle (Chelonia mydas). Herpetol. Rev. 47: 27-32. 
Bird, C.N., Dawn, A.H., Dale, J., and Johnston, D.W. 2020. A semi-automated method for estimating Adélie penguin colony abundance from a fusion of multispectral and thermal imagery collected with unoccupied aircraft systems. Remote Sens. 12: 3692. doi: 10.3390/rs12223692.

Borrelle, S.B., and Fletcher, A.T. 2017. Will drones reduce investigator disturbance to surface-nesting birds? Mar. Ornithol. 45: 89-94.

Bröker, K.C.A., Hansen, R.G., Leonard, K.E., Koski, W.R., and Heide-Jørgensen, M.P. 2019. A comparison of image and observer based aerial surveys of narwhal. Mar. Mamm. Sci. 35: 1253-1279. doi: 10.1111/mms.12586.

Burke, C., Rashman, M.F., Longmore, S.N., McAree, O., Glover-Kapfer, P., Ancrenaz, M., and Wich, S.A. 2019. Successful observation of orangutans in the wild with thermal-equipped drones. J. Unmanned Veh. Syst. 7: 235-257. doi: 10.1139/juvs-2018-0035.

Centelleghe, C., Carraro, L., Gonzalvo, J., Rosso, M., Esposti, E., Gili, C., et al. 2020. The use of unmanned aerial vehicles (UAVs) to sample the blow microbiome of small cetaceans. PLoS ONE, 15: e0235537. doi: 10.1371/ journal.pone.0235537. PMID: 32614926.

Chabot, D. 2009. Systematic evaluation of a stock unmanned aerial vehicle (UAV) system for small-scale wildlife survey applications. Masters thesis, McGill University, Montreal.

Chabot, D., and Bird, D.M. 2012. Evaluation of an off-the-shelf unmanned aircraft system for surveying flocks of geese. Waterbirds, 35: 170-174. doi: 10.1675/063.035.0119.

Chabot, D., and Bird, D.M. 2015. Wildlife research and management methods in the 21st century: Where do unmanned aircraft fit in? J. Unmanned Veh. Syst. 3: 137-155. doi: 10.1139/juvs-2015-0021.

Cheng, E. 2015. Aerial photography and videography using drones. Peachpit Press, San Francisco, California, USA.

Christiansen, F., Dujon, A.M., Sprogis, K.R., Arnould, J.P.Y., and Bejder, L. 2016. Noninvasive unmanned aerial vehicle provides estimates of the energetic cost of reproduction in humpback whales. Ecosphere, 7: e01468. doi: 10.1002/ecs2.1468.

Christiansen, F., Sironi, M., Moore, M.J., Di Martino, M., Ricciardi, M., Warick, H.A., et al. 2019. Estimating body mass of free-living whales using aerial photogrammetry and 3D volumetrics. Methods Ecol. Evol. 10: 2034-2044. doi: 10.1111/2041-210X.13298.

Christiansen, F., Vivier, F., Charlton, C., Ward, R., Amerson, A., Burnell, S., and Bejder, L. 2018. Maternal body size and condition determine calf growth rates in southern right whales. Mar. Ecol. Prog. Ser. 592: 267-281. doi: $10.3354 /$ meps12522.

Christie, K.S., Gilbert, S.L., Brown, C.L., Hatfield, M., and Hanson, L. 2016. Unmanned aircraft systems in wildlife research: Current and future applications of a transformative technology. Front. Ecol. Environ. 14: 241-251. doi: $10.1002 / f e e .1281$.

Clarke, R., and Moses, L.B. 2014. The regulation of civilian drones' impacts on public safety. Comput. Law Secur. Rev. 30: 263-285. doi: 10.1016/j. clsr.2014.03.007.

Coifman, B., McCord, M., Mishalani, R.G., Iswalt, M., and Ji, Y. 2006. Roadway traffic monitoring from an unmanned aerial vehicle. IEE Intell. Transp. Syst. 153: 11-20.

Colefax, A.P., Butcher, P.A., and Kelaher, B.P. 2018. The potential for unmanned aerial vehicles (UAVs) to conduct marine fauna surveys in place of manned aircraft. ICES J. Mar. Sci. 75: 1-8.

Colefax, A.P., Butcher, P.A., Pagendam, D.E., and Kelaher, B.P. 2019. Reliability of marine faunal detections in dronebased monitoring. Ocean Coast. Manag. 174: 108-115. doi: 10.1016/j.ocecoaman.2019.03.008.

Dines, S., and Gennari, E. 2020. First observations of white sharks (Carcharodon carcharias) attacking a live humpback whale (Megaptera novaeangliae). Mar. Freshw. Res. 71: 1205-1210. doi: 10.1071/MF19291.

dos Santos, J.W., Correia, R.A., Malhado, A.C.M., Campos-Silva, J.V., Teles, D., Jepson, P., and Ladle, R.J. 2020. Drivers of taxonomic bias in conservation research: A global analysis of terrestrial mammals. Anim. Conserv. 23: 679-688. doi: 10.1111/acv.12586.

Durban, J.W., Fearnbach, H., Barrett-Lennard, L.G., Perryman, W.L., and Leroi, D.J. 2015. Photogrammetry of killer whales using a small hexacopter launched at sea. J. Unmanned Veh. Syst. 3: 131-135. doi: 10.1139/juvs-2015-0020.

Erbe, C., Parsons, M., Duncan, A., Osterrieder, S.K., and Allen, K. 2017. Aerial and underwater sound of unmanned aerial vehicles (UAV). J. Unmanned Veh. Syst. 5: 92-101. doi: 10.1139/juvs-2016-0018.

Ezat, M.A., Fritsch, C.J., and Downs, C.T. 2018. Use of an unmanned aerial vehicle (drone) to survey Nile crocodile populations: A case study at Lake Nyamithi, Ndumo game reserve, South Africa. Biol. Conserv. 223: 76-81. doi: 10.1016/j.biocon.2018.04.032.

Fettermann, T., Fiori, L., Bader, M., Doshi, A., Breen, D., Stockin, K.A., and Bollard, B. 2019. Behaviour reactions of bottlenose dolphins (Tursiops truncatus) to multirotor unmanned aerial vehicles (UAVs). Sci. Rep. 9: 8558. doi: 10.1038/s41598-019-44976-9. PMID: 31189946.

Fiori, L., Doshi, A., Martinez, E., Orams, M.B., and Bollard-Breen, B. 2017. The use of unmanned aerial systems in marine mammal research. Remote Sens. 9: 543. doi: 10.3390/rs9060543.

Floreano, D., and Wood, R.J. 2015. Science, technology and the future of small autonomous drones. Nature, 521: 460-466. doi: 10.1038/nature14542. PMID: 26017445.

Francis, R.J., Lyons, M.B., Kingsford, R.T., and Brandis, K.J. 2020. Counting mixed breeding aggregations of animal species using drones: Lessons from waterbirds on semi-automation. Remote Sens. 12: 1185. doi: 10.3390/ rs12071185.

Frankelius, P., Norrman, C., and Johansen, K. 2019. Agricultural innovation and the role of institutions: lessons from the game of drones. J. Agric. Environ. Ethics, 32: 681-707. doi: 10.1007/s10806-017-9703-6.

Frid, A., and Dill, L. 2002. Human-caused disturbance stimuli as a form of predation risk. Conserv. Ecol. 6: 11. doi: 10.5751/ES-00404-060111. 
Frixione, M.G., Gómez García, M.J., and Gauger, M.F.W. 2020. Drone imaging of elasmobranchs: Whale sharks and golden cownose rays co-occurrence in a zooplankton hot-spot in southwestern Sea of Cortez. Food Webs, 24: e00155. doi: 10.1016/j.fooweb.2020.e00155.

Fu, Y., Kinniry, M., and Kloepper, L.N. 2018. The Chirocopter: A UAV for recording sound and video of bats at altitude. Methods Ecol. Evol. 9: 1531-1535. doi: 10.1111/2041-210X.12992.

Gallagher, A.J., Papastamatiou, Y.P., and Barnett, A. 2018. Apex predatory sharks and crocodiles simultaneously scavenge a whale carcass. J. Ethol. 36: 205-209. doi: 10.1007/s10164-018-0543-2.

Gardner, S., Leroi, D., and Perryman, W. 2010. A penguin population polar express: NOAA's quest to count penguin breeds speeds up with a VTOL UAS. Unmanned Syst. 29: 30-35.

Geoghegan, J.L., Pirotta, V., Harvey, E., Smith, A., Buchmann, J.P., Ostrowski, M., et al. 2018. Virological sampling of inaccessible wildlife with drones. Viruses, 10: 300. doi: 10.3390/v10060300.

Goebel, M.E., Perryman, W.L., Hinke, J.T., Krause, D.J., Hann, N.A., Gardner, S., and LeRoi, D.J. 2015. A small unmanned aerial system for estimating abundance and size of Antarctic predators. Polar Biol. 38: 619-630. doi: 10.1007/s00300-014-1625-4.

Gooday, O.J., Key, N., Goldstien, S., and Zawar-Reza, P. 2018. An assessment of thermal-image acquisition with an unmanned aerial vehicle (UAV) for direct counts of coastal marine mammals ashore. J. Unmanned Veh. Syst. 6: 100-108. doi: 10.1139/juvs-2016-0029.

Gray, P.C., Fleishman, A.B., Klein, D.J., McKown, M.W., Bézy, V.S., Lohmann, K.J., and Johnston, D.W. 2019. A convolutional neural network for detecting sea turtles in drone imagery. Methods Ecol. Evol. 10: 345-355. doi: 10.1111/ 2041-210X.13132.

Guo, X., Shao, Q., Li, Y., Wang, Y., Wang, D., Liu, J., Fan, J., and Yang, F. 2018. Application of UAV remote sensing for a population census of large wild herbivores - Taking the Headwater Region of the Yellow River as an example. Remote Sens. 10: 1041. doi: 10.3390/rs10071041.

Haalck, L., Mangan, M., Webb, B., and Risse, B. 2020. Towards image-based animal tracking in natural environments using a freely moving camera. J. Neurosci. Methods, 330: 108455. doi: 10.1016/j.jneumeth.2019.108455. PMID: 31739118.

Hahn, N., Mwakatobe, A., Konuche, J., de Souza, N., Keyyu, J., Goss, M., et al. 2017. Unmanned aerial vehicles mitigate human-elephant conflict on the borders of Tanzanian Parks: A case study. Oryx, 51: 513-516. doi: $10.1017 /$ S0030605316000946.

Han, Y., Yoo, S.H., and Kwon, O. 2017. Possibility of applying unmanned aerial vehicle (UAV) and mapping software for the monitoring of waterbirds and their habitats. J. Ecol. Environ. 41: 21. doi: 10.1186/s41610-017-0040-5.

He, G., Yang, H., Pan, R., Sun, Y., Zheng, P., Wang, J., et al. 2020. Using unmanned aerial vehicles with thermalimage acquisition cameras for animal surveys: A case study on the Sichuan snub-nosed monkey in the Qinling Mountains. Integr. Zool. 15: 79-86. doi: 10.1111/1749-4877.12410. PMID: 31305022.

Hensel, E., Wenclawski, S., and Layman, C.A. 2018. Using a small, consumer-grade drone to identify and count marine megafauna in shallow habitats. Lat. Am. J. Aquat. Res. 46: 1025-1033. doi: 10.3856/vol46-issue5-fulltext-15.

Hodgson, A., Kelly, N., and Peel, D. 2013. Unmanned aerial vehicles (UAVs) for surveying marine fauna: A dugong case study. PLoS ONE, 8: e79556. doi: 10.1371/journal.pone.0079556. PMID: 24223967.

Hodgson, J.C., Holman, D., Terauds, A., Koh, L.P., and Goldsworthy, S.D. 2020. Rapid condition monitoring of an endangered marine vertebrate using precise, non-invasive morphometrics. Biol. Conserv. 242: 108402 doi: 10.1016/j.biocon.2019.108402.

Hong, S., Han, Y., Kim, S., Lee, A., and Kim, G. 2019. Application of deep-learning methods to bird detection using unmanned aerial vehicle imagery. Sensors, 19: 1651. doi: 10.3390/s19071651.

Horton, T.W., Hauser, N., Cassel, S., Klaus, K.F., Fettermann, T., and Key, N. 2019. Doctor Drone: non-invasive measurement of humpback whale vital signs using unoccupied aerial system infrared thermography. Front. Mar. Sci. 6: 466. doi: $10.3389 /$ fmars.2019.00466.

Houston, A. I., Prosser, E., and Sans, E. 2012. The cost of disturbance: A waste of time and energy? Oikos, 121: 597-604. doi: 10.1111/j.1600-0706.2011.19594.X.

Inman, V.L., Kingsford, R.T., Chase, M.J., and Leggett, K.E.A. 2019. Drone-based effective counting and ageing of hippopotamus (Hippopotamus amphibius) in the Okavango Delta in Botswana. PLoS ONE, 14: e0219652. doi: 10.1371/journal.pone.0219652. PMID: 31805046.

Inoue, S., Yamamoto, S., Ringhofer, M., Mendonça, R.S., Pereira, C., and Hirata, S. 2019. Spatial positioning of individuals in a group of feral horses: A case study using drone technology. Mamm. Res. 64: 249-259. doi: 10.1007/s13364-018-0400-2.

Israel, M. 2011. A UAV-based roe deer fawn detection system. Int. Arch. Photogramm. Remote Sens. Spatial Inf. Sci. XXXVIII-1: 51-55.

Jarrett, D., Calladine, J., Cotton, A., Wilson, M.W., and Humphreys, E. 2020. Behavioural responses of non-breeding waterbirds to drone approach are associated with flock size and habitat. Bird Study, 67: 190-196. doi: 10.1080/ 00063657.2020 .1808587$.

Jech, J.M., Johnson, J.J., Lutcavage, M., Vanderlaan, A.S.M., Rzhanov, Y., and LeRoi, D. 2020. Measurements of juvenile Atlantic bluefin tuna (Thunnus thynnus) size using an unmanned aerial system. J. Unmanned Veh. Syst. 8: 140-160. doi: 10.1139/juvs-2018-0039.

Jones, G.P. 2003. Feasibility of using small unmanned aerial vehicles for wildlife research. PhD thesis, University of Florida, Gainesville, Florida.

Junda, J., Greene, E., and Bird, D.M. 2015. Proper flight technique for using a small rotary-winged drone aircraft to safely, quickly, and accurately survey raptor nests. J. Unmanned Veh. Syst. 3: 222-236. doi: 10.1139/juvs-2015-0003. 
Kays, R., Sheppard, J., Mclean, K., Welch, C., Paunescu, C., Wang, V., Kravit, G., and Crofoot, M. 2019. Hot monkey, cold reality: Surveying rainforest canopy mammals using drone-mounted thermal infrared sensors. Int. J. Remote Sens. 40: 407-419. doi: 10.1080/01431161.2018.1523580.

Kelaher, B.P., Colefax, A.P., Tagliafico, A., Bishop, M.J., Giles, A., and Butcher, P.A. 2020. Assessing variation in assemblages of large marine fauna off ocean beaches using drones. Mar. Freshw. Res. 71: 68-77. doi: 10.1071/ MF18375.

Kellenberger, B., Marcos, D., and Tuia, D. 2018. Detecting mammals in UAV images: Best practices to address a substantially imbalanced dataset with deep learning. Remote Sens. Environ. 216: 139-153. doi: 10.1016/ j.rse.2018.06.028.

Kiszka, J.J., Mourier, J., Gastrich, K., and Heithaus, M.R. 2016. Using unmanned aerial vehicles (UAVs) to investigate shark and ray densities in a shallow coral lagoon. Mar. Ecol. Prog. Ser. 560: 237-242. doi: 10.3354/meps11945.

Kloepper, L.N., and Kinniry, M. 2018. Recording animal vocalizations from a UAV: Bat echolocation during roost re-entry. Sci. Rep. 8: 7779. doi: 10.1038/s41598-018-26122-z. PMID: 29773821.

Koh, L.P., and Wich, S.A. 2012. Dawn of drone ecology: Low-cost autonomous aerial vehicles for conservation. Trop. Conserv. Sci. 5: 121-132. doi: 10.1177/194008291200500202.

Korczak-Abshire, M., Kidawa, A., Zmarz, A., Storvold, R., Karlsen, S.R., Rodzewicz, M., Chwedorzewska, K., and Znój, A. 2016. Preliminary study on nesting Adélie penguins disturbance by unmanned aerial vehicles. CCAMLR Sci. 23: 1-16.

Korczak-Abshire, M., Zmarz, A., Rodzewicz, M., Kycko, M., Karsznia, I., and Chwedorzewska, K.J. 2019. Study of fauna population changes on Penguin Island and Turret Point Oasis (King George Island, Antarctica) using an unmanned aerial vehicle. Polar Biol. 42: 217-224. doi: 10.1007/s00300-018-2379-1.

Koski, W.R., Thomas, T.A., Funk, D.W., and Macrander, A.M. 2013. Marine mammal sightings by analysts of digital imagery versus aerial surveyors: A preliminary comparison. J. Unmanned Veh. Syst. 1: 25-40. doi: 10.1139/juvs2013-0015.

Krause, D.J., Hinke, J.T., Perryman, W.L., Goebel, M.E., and LeRoi, D.J. 2017. An accurate and adaptable photogrammetric approach for estimating the mass and body condition of pinnipeds using an unmanned aerial system. PLoS ONE, 12: e0187465. doi: 10.1371/journal.pone.0187465. PMID: 29186134.

Lachman, D., Conway, C., Vierling, K., and Matthews, T. 2020. Drones provide a better method to find nests and estimate nest survival for colonial waterbirds: A demonstration with western grebes. Wetl. Ecol. Manag. 28: 837-845. doi: 10.1007/s11273-020-09743-y.

Lea, J.S.E., Daly, R., Leon, C., Daly, C., and Clarke, C. 2018. Life after death: Behaviour of multiple shark species scavenging a whale carcass. Mar. Freshw. Res. 70: 302e306. doi: 10.1071/MF18157.

Lee, W.Y., Park, M., and Hyun, C. 2019. Detection of two Arctic birds in Greenland and an endangered bird in Korea using RGB and thermal cameras with an unmanned aerial vehicle (UAV). PLoS ONE, 14: e0222088. doi: 10.1371/ journal.pone.0222088. PMID: 31483842.

Liu, C.C., Chen, Y.H., and Wen, H.L. 2015. Supporting the annual international black-faced spoonbill census with a low-cost unmanned aerial vehicle. Ecol. Inform. 30: 170-178. doi: 10.1016/j.ecoinf.2015.10.008.

Mapes, K.L., Pricope, N.G., Baxley, J.B., Schaale, L.E., and Danner, R.M. 2020. Thermal imaging of beach-nesting bird habitat with unmanned aerial vehicles: Considerations for reducing disturbance and enhanced image accuracy. Drones, 4: 12. doi: 10.3390/drones4020012.

Marion, S., Davies, A., Demšar, U., Irvine, R.J., Stephens, P.A., and Long, J. 2020. A systematic review of methods for studying the impacts of outdoor recreation on terrestrial wildlife. Glob. Ecol. Conserv. 22: e00917. doi: 10.1016/ j.gecco.2020.e00917.

Martin, J., Edwards, H.H., Burgess, M.A., Percival, H.F., Fagan, D.E., Gardner, B.E., et al. 2012. Estimating distribution of hidden objects with drones: From tennis balls to manatees. PLoS ONE 7: e38882. doi: 10.1371/ journal.pone.0038882.

McClelland, G.T.W., Bond, A.L., Sardana, A., and Glass, T. 2016. Rapid population estimate of a surface-nesting seabird on a remote island using a low-cost unmanned aerial vehicle. Mar. Ornithol. 44: 215-220.

McEvoy, J.F., Hall, G.P., and McDonald, P.G. 2016. Evaluation of unmanned aerial vehicle shape, flight path and camera type for waterfowl surveys: Disturbance effects and species recognition. PeerJ, 4: e1831. doi: 10.7717| peerj.1831. PMID: 27020132.

McIntosh, R.R., Holmberg, R., and Dann, P. 2018. Looking without landing - Using remote piloted aircraft to monitor fur seal populations without disturbance. Front. Mar. Sci. 5: 202. doi: 10.3389/fmars.2018.00202.

Mesquita, G.P., Rodríguez-Teijeiro, J.D., Wich, S.A., and Mulero-Pázmány, M. 2020. Measuring disturbance at swift breeding colonies due to the visual aspects of a drone: A quasi-experiment study. Curr. Zool. 67: 157-163. doi: 10.1093/cz/zoaa038. PMID: 33854533.

Mo, M., and Bonatakis, K. 2022. Approaching wildlife with drones: Using scientific literature to identify factors to consider for minimising disturbance. Aust. Zool. 42: 1-29. doi: 10.7882/AZ.2021.015.

Mulero-Pázmány, M., Stolper, R., van Essen, L.D., Negro, J.J., and Sassen, T. 2014. Remotely piloted aircraft systems as a rhinoceros anti-poaching tool in Africa. PLoS ONE, 9: e83873. doi: 10.1371/journal.pone.0083873. PMID: 24416177.

Mustafa, O., Barbosa, A., Krause, D.J., Peters, H., Vieira, G., and Rümmler, M. 2018. State of knowledge: Antarctic wildlife response to unmanned aerial systems. Polar Biol. 41: 2387-2398. doi: 10.1007/s00300-018-2363-9.

Nakajima, K., Seo, K., Inoue, M., Shiotsuki, T., and Koizumi, H. 2019. Development of drone systems for prevention of bird damage. J. Jap. Soc. Agric. Mach. Food Eng. 81: 112-119. 
Nelson, T.M., Wallen, M.M., Bunce, M., Oskam, C.L., Lima, N., Clayton, L., and Mann, J. 2019. Detecting respiratory bacterial communities of wild dolphins: Implications for animal health. Mar. Ecol. Prog. Ser. 622: 203-217. doi: 10.3354/meps13055.

Oliveira-da-Costa, M., Marmontel, , M., Da-Rosa, D., Coelho, A., Wich, S., Mosquera-Guerra, F., and Trujillo, F. 2020. Effectiveness of unmanned aerial vehicles to detect Amazon dolphins. Oryx, 54: 696-698. doi: 10.1017/ S0030605319000279.

Oosthuizen, W.C., Krüger, L., Jouanneau, W., and Lowther, A.D. 2020. Unmanned aerial vehicle (UAV) survey of the Antarctic shag (Leucocarbo bransfieldensis) breeding colony at Harmony Point, Nelson Island, South Shetland Islands. Polar Biol. 43: 187-191. doi: 10.1007/s00300-019-02616-y.

Pfeifer, C., Barbosa, A., Mustafa, O., Peter, H., Rümmler, M., and Brenning, A. 2019. Using fixed-wing UAV for detecting and mapping the distribution and abundance of penguins on the South Shetlands Islands, Antarctica. Drones, 3: 39. doi: 10.3390/drones3020039.

Pirotta, V., Smith, A., Ostrowski, M., Russell, D., Jonsen, I.D., Grech, A., and Harcourt, R. 2017. An economical custom-built drone for assessing whale health. Front. Mar. Sci. 4: 425. doi: 10.3389/fmars.2017.00425.

Pomeroy, P., Connor, L.O., and Davies, P. 2015. Assessing use of and reaction to unmanned aerial systems in gray and harbor seals during breeding and molt in the UK. J. Unmanned Veh. Syst. 3: 102-113. doi: 10.1139/juvs-20150013.

Porter, M.E., Ruddy, B.T., and Kajiura, S.M. 2020. Volitional swimming kinematics of blacktip sharks, Carcharhinus limbatus, in the wild. Drones, 4: 78. doi: 10.3390/drones4040078.

Potapov, E.R., Utekhina, I.G., McGrady, M.J., and Rimlinger, D. 2013. Usage of UAV for surveying Steller's sea eagle nests. Raptors Conserv. 27: 253-260.

Racanelli, V., Bartolozzi, S., Sorbetti Guerri, E., and Sorbetti Guerri, F. 2018. Use of remotely piloted aerial systems (R.P.A.S.) for wildlife monitoring. Proceedings of the 17th International Scientific Conference - Engineering for Rural Development, 23-25 May 2018, Jelgava, Latvia. pp. 1611-1617.

Radiansyah, S., Kusrini, M.D., and Prasetyo, L.B. 2017. Quadcopter applications for wildlife monitoring. IOP Conf. Ser. Earth Environ. Sci. 54: 012066. doi: 10.1088/1755-1315/54/1/012066.

Ramos, E.A., Maloney, B., Magnasco, M.O., and Reiss, D. 2018. Bottlenose dolphins and Antillean manatees respond to small multi-rotor unmanned aerial systems. Front. Mar. Sci. 5: 316. doi: 10.3389/fmars.2018.00316.

Rao, B., Gopi, A.G., and Maione, R. 2016. The societal impact of commercial drones. Technol. Soc. 45: 83-90. doi: $10.1016 / j$. techsoc.2016.02.009.

Raoult, V., Colefax, A.P., Allan, B.M., Cagnazzi, D., Castelblanco-Martínez, N., Ierodiaconou, D., et al. 2020. Operational protocols for the use of drones in marine animal research. Drones, 4: 64. doi: 10.3390/drones4040064.

Raoult, V., Tosetto, L., and Williamson, J.E. 2018. Drone-based high-resolution tracking of aquatic vertebrates. Drones, 2: 37. doi: 10.3390/drones2040037.

Ratcliffe, N., Guihen, D., Robst, J., Crofts, S., Stanworth, A., and Enderlein, P. 2015. A protocol for the aerial survey of penguin colonies using UAVs. J. Unmanned Veh. Syst. 3: 95-101. doi: 10.1139/juvs-2015-0006.

Raudino, H.C., Tyne, J.A., Smith, A., Ottewell, K., McArthur, S., Kopps, A.M., et al. 2019. Challenges of collecting blow from small cetaceans. Ecosphere, 10: e02901. doi: 10.1002/ecs2.2901.

Rebolo-Ifrán, N., Graña Grilli, M., and Lambertucci, S.A. 2019. Drones as a threat to wildlife: YouTube complements science in providing evidence about their effect. Environ. Conserv. 46: 205-210. doi: 10.1017/S0376892919000080.

Rees, A.F., Avens, L., Ballorain, K., Bevan, E., Broderick, A.C., Carthy, R.R., et al. 2018. The potential of unmanned aerial systems for sea turtle research and conservation: A review and future directions. Endanger. Species Res. 35: 81-100. doi: 10.3354/esr00877.

Reid, M. 2014. Grounding drones: Big Brother's tool box needs regulation not elimination. Richmond J. Law Technol. 20: 9. doi: 10.2139/ssrn.2357657.

Restas, A. 2015. Drone applications for supporting disaster management. World J. Eng. Technol. 3: 316-321. doi: 10.4236/wjet.2015.33C047.

Rieucau, G., Kiszka, J.J., Castillo, J.C., Mourier, J., Boswell, K.M., and Heithaus, M.R. 2018. Using unmanned aerial vehicle (UAV) surveys and image analysis in the study of large surface-associated marine species: A case study on reef sharks Carcharhinus melanopterus shoaling behaviour. J. Fish Biol. 93: 119-127. doi: 10.1111/jfb.13645. PMID: 29855056.

Rümmler, M., Mustafa, O., Maercker, J., Peter, H., and Esefeld, J. 2016. Measuring the influence of unmanned aerial vehicles on Adélie penguins. Polar Biol. 39: 1329-1334. doi: 10.1007/s00300-015-1838-1.

Rümmler, M., Mustafa, O., Maercker, J., Peter, H., and Esefeld, J. 2018. Sensitivity of Adélie and gentoo penguins to various flight activities of a micro UAV. Polar Biol. 41: 2481-2493. doi: 10.1007/s00300-018-2385-3.

Rush, G.P., Clarke, L.E., Stone, M., and Wood, M.J. 2018. Can drones count gulls? Minimal disturbance and semiautomated image processing with an unmanned aerial vehicle for colony-nesting seabirds. Ecol. Evol. 8: 12322-12334. doi: 10.1002/ece3.4495. PMID: 30619548.

Sardà-Palomera, F., Bota, G., Padilla, N., Brotons, L., and Sardà, F. 2017. Unmanned aircraft systems to unravel spatial and temporal factors affecting dynamics of colony formation and nesting success in birds. J. Avian Biol. 48: 1273-1280. doi: 10.1111/jav.01535.

Sardà-Palomera, F., Bota, G., Viñolo, C., Pallarés, O., Sazatornil, V., Brotons, L., Gomáriz, S., and Sardà, F. 2012. Finescale bird monitoring from light unmanned aircraft systems. Ibis, 154: 177-183. doi: 10.1111/j.1474919X.2011.01177.x.

Sasse, D.B. 2003. Job-related mortality of wildlife workers in the United States, 1937-2000. Wildl. Soc. Bull. 31: 1015-1020. 
Schofield, G., Esteban, N., Katselidis, K.A., and Hays, G.C. 2019. Drones for research on sea turtles and other marine vertebrates - A review. Biol. Conserv. 238: 108214. doi: 10.1016/j.biocon.2019.108214.

Schofield, G., Katselidis, K.A., Lilley, M.K.S., Reina, R.D., and Hays, G.C. 2017. Detecting elusive aspects of wildlife ecology using drones: New insights on the mating dynamics and operational sex ratios of sea turtles. Funct. Ecol. 31: 2310-2319. doi: 10.1111/1365-2435.12930.

Schopfel, J., Chaudiron, S., Jacquemin, B., Prost, H., Severo, M., and Thiault, F. 2014. Open access to research data in electronic theses and dissertations: an overview. Libr. Hi Tech. 32: 612-627. doi: 10.1108/LHT-06-2014-0058.

Schroeder, N.M., Panebianco, A., Gonzalez Musso, R., and Carmanchahi, P. 2020. An experimental approach to evaluate the potential of drones in terrestrial mammal research: A gregarious ungulate as a study model. R. Soc. Open Sci. 7: 191482. doi: 10.1098/rsos.191482. PMID: 32218965.

Scobie, C.A., and Hugenholtz, C.H. 2016. Wildlife monitoring with unmanned aerial vehicles: Quantifying distance to auditory detection. Wildl. Soc. Bull. 40: 781-785. doi: 10.1002/wsb.700.

Selby, W., Corke, P., and Rus, D. 2011. Autonomous aerial navigation and tracking of marine mammals. Proceedings of the 2011 Australasian Conference on Robotics and Automation, 7-9 December 2011, Melbourne, Australia. pp. 1-7.

Semel, B.P., Karpantya, S.M., Vololonirina, F.F., and Rakotonanahary, A.N. 2020. Eyes in the sky: Assessing the feasibility of low-cost, ready-to-use unmanned aerial vehicles to monitor primate populations directly. Folia Primatol. 91: 69-82. doi: 10.1159/000496971.

Siyuan, C. 2015. The regulation of the recreational use of drones for aerial photography and videography: Comparing Singapore's Unmanned Aircraft Act with other legislation. Singapore Law Rev. 55: 1-37.

Sizo, A., Lino, A., Reis, L.P., and Rocha, Á. 2019. An overview of assessing the quality of peer review reports of scientific articles. Int. J. Inform. Manag. 46: 286-293. doi: 10.1016/j.ijinfomgt.2018.07.002.

Smith, C.E., Sykora-Bodie, S.T., Bloodworth, B., Pack, S.M., Spradlin, T.R., and LeBoeuf, N.R. 2016. Assessment of known impacts of unmanned aerial systems (UAS) on marine mammals: Data gaps and recommendations for researchers in the United States. J. Unmanned Veh. Syst. 1: 31-44. doi: 10.1139/juvs-2015-0017.

Su, X., Dong, S., Liu, S., Cracknell, A.P., Zhang, Y., Wang, X., and Liu, G. 2018. Using an unmanned aerial vehicle (UAV) to study wild yak in the highest desert in the world. Int. J. Remote Sens. 39: 5490-5503. doi: 10.1080/ 01431161.2018.1441570.

Sykora-Bodie, S.T., Bezy, V., Johnston, D.W., Newton, E., and Lohmann, K.J. 2017. Quantifying nearshore sea turtle densities: Applications of unmanned aerial systems for population assessments. Sci. Rep. 7: 17690. doi: 10.1038/ s41598-017-17719-x. PMID: 29255157.

Thapa, G.J., Thapa, K., Thapa, R., Jnawali, S.R., Wich, S.A., Poudyal, L.P., and Karki, S. 2018. Counting crocodiles from the sky: monitoring the critically endangered gharial (Gavialis gangeticus) population with an unmanned aerial vehicle (UAV). J. Unmanned Veh. Syst. 6: 71-82. doi: 10.1139/juvs-2017-0026

Torres, L.G., Nieukirk, S.L., Lemos, L., and Chandler, T.E. 2018. Drone up! Quantifying whale behavior from a new perspective improves observational capacity. Front. Mar. Sci. 5: 319. doi: 10.3389/fmars.2018.00319.

Tripicchio, P., Satler, M., Dabisias, G., Ruffaldi, E., and Avizzano, C.A. 2015. Towards smart farming and sustainable agriculture with drones. International Conference on Intelligent Environments, Prague, Czech Republic, 15-17 July 2015. pp. 140-143.

Tucker, J.P., Vercoe, B., Santos, I.R., Dujmovic, M., and Butcher, P.A. 2019. Whale carcass scavenging by sharks. Global Ecol. Conserv. 19: e00655. doi: 10.1016/j.gecco.2019.e00655.

Valle, R.G., and Scarton, F. 2018. Uso dei droni nel censimento degli uccelli acquatici nidificanti nel Nord Adatico. Boll. Mus. Stor. Nat. Venezia, 69: 69-75.

Valle, R.G., and Scarton, F. 2019. Effectiveness, efficiency, and safety of censusing Eurasian oystercatchers Haematopus ostralegus by unmanned aircraft. Mar. Ornithol. 47: 87-93.

Valle, R.G., and Scarton, F. 2020. Drones improve effectiveness and reduce disturbance of censusing common redshanks Tringa totanus breeding on salt marshes. Ardea, 107: 275-282. doi: 10.5253/arde.v107i3.a3.

Vas, E., Lescroël, A., Duriez, O., Boguszewski, G., and Grémillet, D. 2015. Approaching birds with drones: first experiments and ethical guidelines. Biol. Lett. 11: 20140754. doi: 10.1098/rsbl.2014.0754.

Vermeulen, C., Lejeune, P., Lisein, J., Sawadogo, P., and Bouche, P. 2013. Unmanned aerial survey of elephants. PLoS ONE, 8: e54700. doi: 10.1371/journal.pone.0054700.

Wallace, P., Martin, R., and White, I. 2018. Keeping pace with technology: Drones, disturbance and policy deficiency. J. Environ. Plan. Manag. 61: 1271-1288. doi: 10.1080/09640568.2017.1353957.

Wandrie, L.J., Klug, P.E., and Clark, M.E. 2019. Evaluation of two unmanned aircraft systems as tools for protecting crops from blackbird damage. Crop Prot. 117: 15-19. doi: 10.1016/j.cropro.2018.11.008.

Wang, D., Shao, Q., and Yue, H. 2019. Surveying wild animals from satellites, manned aircraft and unmanned aerial systems (UASs): A review. Remote Sens. 11: 1308. doi: 10.3390/rs11111308.

Warembourg, C., Berger-González, M., Alvarez, D., Sousa, F.M., Hernández, A.L., Roquel, P., et al. 2020. Estimation of free-roaming domestic dog population size: Investigation of three methods including an Unmanned Aerial Vehicle (UAV) based approach. PLoS ONE, 15: e0225022. doi: 10.1371/journal.pone.0225022.

Weimerskirch, H., Prudor, A., and Schull, Q. 2018. Flights of drones over sub-Antarctic seabirds show species and status-specific behavioural and physiological responses. Polar Biol. 41: 259-266. doi: 10.1007/s00300-017-2187-z.

Weissensteiner, M.H., Poelstra, J.W., and Wolf, J.B.W. 2015. Low-budget ready-to-fly unmanned aerial vehicles: An effective tool for evaluating the nesting status of canopy-breeding bird species. J. Avian Biol. 46: 425-430. doi: 10.1111/jav.00619. 
Weston, M.A., O’Brien, C., Kostoglou, K.N., and Symonds, M.R.E. 2020. Escape responses of terrestrial and aquatic birds to drones: Towards a code of practice to minimize disturbance. J. Appl. Ecol. 57: 777-785. doi: 10.1111/13652664.13575.

Witczuk, J., Pagacz, S., Zmarz, A., and Cypel, M. 2018. Exploring the feasibility of unmanned aerial vehicles and thermal imaging for ungulate surveys in forests - Preliminary results. Int. J. Remote Sens. 39: 5504-5521. doi: 10.1080/01431161.2017.1390621.

Wu, F., Zhu, W., Wu, B., and Zhao, X. 2019. Method of automatic counting of large herbivores from UAV images in the Source Region of Three Rivers. Acta Theriol. Sin. 39: 450. doi: 10.16829/j.slxb.150329.

Yang, F., Shao, Q., and Jiang, Z. 2019. A population census of large herbivores based on UAV and its effects on grazing pressure in the Yellow-River-Source National Park, China. Int. J. Environ. Res. Public Health, 16: 4402. doi: 10.3390/ijerph16224402.

Zmarz, A., Rodzewicz, M., Dąbski, M., Karsznia, I., Korczak-Abshire, M., and Chwedorzewska, K.J. 2018. Application of UAV BVLOS remote sensing data for multi-faceted analysis of Antarctic ecosystem. Remote Sens. Environ. 217: 375-388. doi: 10.1016/j.rse.2018.08.031.

\section{Appendix A}

Table A1. List of scientific publications describing or providing commentary of practices involving drones approaching wildlife from 2000 to 2020.

Abd-Elrahman, A., Pearlstine, L., and Percival, F. 2005. Development of pattern recognition algorithm for automatic bird detection from unmanned aerial vehicle imagery. Surv. Land Inf. Sci. 65: 37.

Acevedo-Whitehouse, K., Rocha-Gosselin, A., and Gendron, D. 2010. A novel non-invasive tool for disease surveillance of free-ranging whales and its relevance to conservation programs. Anim. Conserv. 13: 217-225.

Adame, K., Pardo, M.A., Salvadeo, C., Beier, E., and Elorriaga-Verplancken, F.R. 2017. Detectability and categorization of California sea lions using an unmanned aerial vehicle. Mar. Mamm. Sci. 33: 913-925.

Adams, K., Broad, A., Ruiz-García, D., and Davis, A.R. 2020. Continuous wildlife monitoring using blimps as an aerial platform: A case study observing marine megafauna. Aust. Zool. 40: 407-415.

Afán, I., Máñez, M., and Díaz-Delgado, R. 2018. Drone monitoring of breeding waterbird populations: The case of the glossy ibis. Drones, 2: 42.

Albores-Barajas, Y.V., Soldatini, C., Ramos-Rodríguez, A., Alcala-Santoyo, J.E., Carmona, R., and Dell'Omo, G. 2018. A new use of technology to solve an old problem: Estimating the population size of a burrow nesting seabird. PLOS ONE, 13: e0202094.

Allan, B.M., Ierodiaconou, D., Hoskins, A.J., and Arnould, J.P. 2019. A rapid UAV method for assessing body condition in fur seals. Drones, 3: 24.

Allport, G. 2016. Fleeing by whimbrel Numenius phaeopus in response to a recreational drone in Maputo Bay, Mozambique. Biodivers. Obs. 7: 44.

Anderson, K., and Gaston, K.J. 2013. Lightweight unmanned aerial vehicles will revolutionize spatial ecology. Front. Ecol. Environ. 11: 138-146.

Angliss, R.P., Hall, F.P., Kennedy, A., and Sformo, T. 2018. Comparing manned to unmanned aerial surveys for cetacean monitoring in the Arctic: Methods and operational results. J. Unmanned Veh. Syst. 6: 109-127.

Aniceto, A.S., Biuw, M., Lindstrøm, U., Solbø, S.A., Broms, F., and Carroll, J. 2018. Monitoring marine mammals using unmanned aerial vehicles: Quantifying detection certainty. Ecosphere, 9: e02122.

Apprill, A., Miller, C.A., Moore, M.J., Durban, J.W., Fearnbach, H., and Barrett-Lennard, L.G. 2017. Extensive core microbiome in drone-captured whale blow supports a framework for health monitoring. mSystems, 2 : e00119-17.

Arona, L., Dale, J., Heaslip, S.G., Hammill, M.O., and Johnston, D.W. 2018. Assessing the disturbance potential of small unoccupied aircraft systems (UAS) on gray seals (Halichoerus grypus) at breeding colonies in Nova Scotia, Canada. PeerJ, 6: e4467.

Barasona, J.A., Mulero-Pázmány, M., Acevedo, P., Negro, J.J., Torres, M.J., Gortázar, C., and Vicente, J. 2014. Unmanned aircraft systems for studying spatial abundance of ungulates: Relevance to spatial epidemiology. PLoS ONE, 9: e115608.

Barnas, A.F.G. 2019. Applications of an unmanned aircraft vehicle and remote cameras for studying a sub-Arctic ecosystem. PhD thesis, University of North Dakota, Grand Forks, North Dakota.

Barnas, A.F., Felege, C.J., Rockwell, R.F., and Ellis-Felege, S.N. 2018. A pilot(less) study on the use of an unmanned aircraft system for studying polar bears (Ursus maritimus). Polar Biol. 41: 1055-1062.

Barnas, A.F., Newman, R., Felege, C.J., Corcoran, M.P., Hervey, S.D., Stechmann, T.J., Rockwell, R.F., and Ellis-Felege, S.N. 2018. Evaluating behavioral responses of nesting lesser snow geese to unmanned aircraft surveys. Ecol. Evol. 8: 1328-1338.

Barr, J.R., Green, M.C., DeMaso, S.J., and Hardy, T.B. 2020. Drone surveys do not increase colony-wide flight behaviour at waterbird nesting sites, but sensitivity varies among species. Sci. Rep. 10: 3781. 
Table A1. (continued).

Beaver, J.T., Baldwin, R.W., Messinger, M., Newbolt, C.H., Ditchkoff, S.S., and Silman, M.R. 2020. Evaluating the use of drones equipped with thermal sensors as an effective method for estimating wildlife. Wildl. Soc. Bull. 44: 434-443.

Bech-Hansen, M., Kallehauge, R.M., Lauritzen, J.M.S., Sørensen, M.S., Laubek, B., Jensen, L.F., Petoldi, C. and Bruhn, D. 2020. Evaluation of disturbance effect on geese caused by an approaching unmanned aerial vehicle. Bird Conserv. Int. 30: 169-175.

Bendel, O. 2018. Towards animal-friendly machines. Paladyn, J. Behav. Robot. 9: 204-213.

Bennitt, E., Bartlam-Brooks, H.L.A., Hubel, T.Y., and Wilson, A.M. 2019. Terrestrial mammalian wildlife responses to unmanned aerial systems approaches. Sci. Rep. 9: 2142.

Beranek, C.T., Roff, A., Denholm, B., Howell, L.G., and Witt, R.R. 2021. Trialling a real-time drone detection and validation protocol for the koala (Phascolarctos cinereus). Aust. Mammal. 43: 260-264.

Bevan, E., Whiting, S., Tucker, T., Guinea, M., Raith, A., and Douglas, R. 2018. Measuring behavioral responses of sea turtles, saltwater crocodiles, and crested terns to drone disturbance to define ethical operating thresholds. PLoS ONE, 13: e0194460.

Bevan, E., Wibbels, T., Najera, B.M.Z., Martinez, M.A.C., Martinez, L.A.S., Martinez, F.I., Cuevas, J.M., Anderson, T., Bonka, A., Hernandez, M.H., Peña, L.J., and Burchfield, P.M. 2015. Unmanned aerial vehicles (UAVs) for monitoring sea turtles in near-shore waters. Mar. Turtle Newsl. 145: 19-22.

Bevan, E., Wibbels, T., Navarro, E., Rosas, M., Najera, B.M.Z., Sarti, L., Illescas, F., Montano, J., Peña, L.J., and Burchfield, P. 2016. Using unmanned aerial vehicle (UAV) technology for locating, identifying, and monitoring courtship and mating behavior in the green turtle (Chelonia mydas). Herpetol. Rev. 47: 27-32.

Bierlich, K., and Johnston, D. 2016. Using unoccupied aerial systems (UAS) for surveying shorebirds in North Carolina. Duke University, Durham, North Carolina.

Bird, C.N., Dawn, A.H., Dale, J., and Johnston, D.W. 2020. A semi-automated method for estimating Adélie penguin colony abundance from a fusion of multispectral and thermal imagery collected with unoccupied aircraft systems. Remote Sens. 12: 3692.

Blight, L.K., Bertram, D.F., and Kroc, E. 2019. Evaluating UAV-based techniques to census an urban-nesting gull population on Canada's Pacific coast. J. Unmanned Veh. Syst. 7: 312-324.

Borrelle, S.B., and Fletcher, A.T. 2017. Will drones reduce investigator disturbance to surface-nesting birds? Mar. Ornithol. 45: 89-94.

Brands, S. 2016. Application of unmanned aerial systems (UAS) in wildlife conservation. PhD thesis, University of Groningen, The Netherlands.

Brisson-Curadeau, É., Bird, D., Burke, C., Fifield, D.A., Pace, P., Sherley, R.B., and Elliott, K.H. 2017. Seabird species vary in behavioural response to drone census. Sci. Rep. 7: 17884.

Bröker, K.C.A., Hansen, R.G., Leonard, K.E., Koski, W.R., and Heide-Jørgensen, M.P. 2019. A comparison of image and observer based aerial surveys of narwhal. Mar. Mamm. Sci. 35: 1253-1279.

Brunton, E.A., Leon, J.X., and Burnett, S.E. 2020. Evaluating the efficacy and optimal deployment of thermal infrared and true-colour imaging when using drones for monitoring kangaroos. Drones, 4: 20.

Brunton, E., Bolin, J., Leon, J., and Burnett, S. 2019. Fright or flight? Behavioural responses of kangaroos to dronebased monitoring. Drones, 3: 41.

Burke, C., Rashman, M., Wich, S., Symons, A., Theron, C., and Longmore, S. 2019. Optimizing observing strategies for monitoring animals using drone-mounted thermal infrared cameras. Int. J. Remote Sens. 40, 439-467.

Burke, C., Rashman, M.F., Longmore, S.N., McAree, O., Glover-Kapfer, P., Ancrenaz, M., and Wich, S.A. 2019. Successful observation of orangutans in the wild with thermal-equipped drones. J. Unmanned Veh. Syst. 7: 235257.

Bushaw, J.D., Ringelman, K.M., and Rohwer, F.C. 2019. Applications of unmanned aerial vehicles to survey mesocarnivores. Drones, 3: 28.

Centelleghe, C., Carraro, L., Gonzalvo, J., Rosso, M., Esposti, E., Gili, C., Bonato, M., Pedrotti, D., Cardazzo, B., Povinelli, M., and Mazzariol, S. 2020. The use of unmanned aerial vehicles (UAVs) to sample the blow microbiome of small cetaceans. PLoS ONE, 15: e0235537.

Chabot, D. 2014. The rise of unmanned aircraft in wildlife science: A review of potential contributions and their application to waterbird research. PhD thesis, McGill University, Montreal.

Chabot, D. 2009. Systematic evaluation of a stock unmanned aerial vehicle (UAV) system for small-scale wildlife survey applications. Masters thesis, McGill University, Montreal.

Chabot, D., and Bird, D.M. 2012. Evaluation of an off-the-shelf unmanned aircraft system for surveying flocks of geese. Waterbirds, 35: 170-174.

Chabot, D., and Bird, D.M. 2015. Wildlife research and management methods in the 21st century: Where do unmanned aircraft fit in? J. Unmanned Veh. Syst. 3: 137-155.

Chabot, D., Craik, S.R., and Bird, D.M. 2015. Population census of a large common tern colony with a small unmanned aircraft. PLoS ONE, 10: e0122588.

Chabot, D., Stapleton, S., and Francis, C.M. 2019. Measuring the spectral signature of polar bears from a drone to improve their detection from space. Biol. Cons. 237: 125-132. 
Table A1. (continued).

Chrétien, L., Théau, J., and Ménard, P. 2015. Wildlife multispecies remote sensing using visible and thermal infrared imagery acquired from an unmanned aerial vehicle (UAV). International Conference on Unmanned Aerial Vehicles in Geomatics. pp. 241-248.

Chrétien, L., Théau, J., Ménard, P. 2016. Visible and thermal infrared remote sensing for the detection of whitetailed deer using an unmanned aerial system. Wildl. Soc. Bull. 40: 181-191.

Christiansen, F., Dujon, A.M., Sprogis, K.R., Arnould, J.P.Y., and Bejder, L. 2016. Noninvasive unmanned aerial vehicle provides estimates of the energetic cost of reproduction in humpback whales. Ecosphere, 7: e01468.

Christiansen, F., Nielsen, M.L.K., Charlton, C., Bejder, L., and Madsen, P.T. 2020. Southern right whales show no behavioral response to low noise levels from a nearby unmanned aerial vehicle. Mar. Mamm. Sci. 36: 953-963.

Christiansen, F., Rojano-Doñate, L., Madsen, P.T., and Bejder, L. 2016. Noise levels of multi-rotor unmanned aerial vehicles with implications for potential underwater impacts on marine mammals. Front. Mar. Sci. 3: 277.

Christiansen, F., Sironi, M., Moore, M.J., Di Martino, M., Ricciardi, M., Warick, H.A., Irschick, D.J., Gutierrez, R., Uhart, M.M., and Iossa, G. 2019. Estimating body mass of free-living whales using aerial photogrammetry and 3D volumetrics. Methods Ecol. Evol. 10: 2034-2044.

Christiansen, F., Vivier, F., Charlton, C., Ward, R., Amerson, A., Burnell, S., and Bejder, L. 2018. Maternal body size and condition determine calf growth rates in southern right whales. Mar. Ecol. Prog. Ser. 592: 267-281.

Christie, K.S., Gilbert, S.L., Brown, C.L., Hatfield, M., and Hanson, L. 2016. Unmanned aircraft systems in wildlife research: Current and future applications of a transformative technology. Front. Ecol. Environ. 14: 241-251.

Colefax, A.P., Butcher, P.A., and Kelaher, B.P. 2018. The potential for unmanned aerial vehicles (UAVs) to conduct marine fauna surveys in place of manned aircraft. ICES J. Mar. Sci. 75: 1-8.

Colefax, A.P., Butcher, P.A., Pagendam, D.E., and Kelaher, B.P. 2019. Reliability of marine faunal detections in drone-based monitoring. Ocean Coast. Manag. 174: 108-115.

Corcoran, E., Denman, S., Hanger, J., Wilson, B., and Hamilton, G. 2019. Automated detection of koalas using low-level aerial surveillance and machine learning. Sci. Rep. 9: 3208.

DiGiacomo, A.E., Harrison, W.E., Johnston, D.W., and Ridge, J.T. 2020. Elasmobranch use of nearshore estuarine habitats responds to fine-scale, intra-seasonal environmental variation: Observing coastal shark density in a temperate estuary utilizing unoccupied aircraft systems (UAS). Drones, 4: 74.

Dines, S., and Gennari, E. 2020. First observations of white sharks (Carcharodon carcharias) attacking a live humpback whale (Megaptera novaeangliae). Mar. Freshw. Res. 71: 1205-1210.

Ditmer, M.A., Vincent, J.B., Werden, L.K., Tanner, J.C., Laske, T.G., Iaizzo, P.A., Garshelis, D.L., and Fieberg, J.R. 2015. Bears show a physiological but limited behavioral response to unmanned aerial vehicles. Curr. Biol. 25: 2278-2283.

Ditmer, M.A., Werden, L.K., Tanner, J.C., Vincent, J.B., Callahan, P., Iaizzo, P.A., Laske, T.G., and Garshelis, D.L. 2019. Bears habituate to the repeated exposure of a novel stimulus, unmanned aircraft systems. Conserv. Physiol. 7: coy067.

Domínguez-Sánchez, C.A., Acevedo-Whitehouse, K.A., and Gendron, D. 2018. Effect of drone-based blow sampling on blue whale (Balaenoptera musculus) behavior. Mar. Mamm. Sci. 34: 841-850.

Drever, M.C., Chabot, D., O’Hara, P.D., Thomas, J.D., Breault, A., and Millikin, R.L. 2015. Evaluation of an unmanned rotorcraft to monitor wintering waterbirds and coastal habitats in British Columbia, Canada. J. Unmanned Veh. Syst. 3: 259-267.

Dulava, S., Bean, W.T., and Richmond, O.M.W. 2015. Environmental reviews and case studies: applications of unmanned aircraft systems (UAS) for waterbird surveys. Environ. Pract. 17: 201-210.

Durban, J.W., Fearnbach, H., Barrett-Lennard, L.G., Perryman, W.L., and Leroi, D.J. 2015. Photogrammetry of killer whales using a small hexacopter launched at sea. J. Unmanned Veh. Syst. 3: 131-135.

Egan, C.C. 2018. Evaluating the potential utility of drones to deter birds from areas of human-wildlife conflict. Masters thesis, North Dakota State University of Agriculture and Applied Science, Fargo, North Dakota.

Erbe, C., Parsons, M., Duncan, A., Osterrieder, S.K., and Allen, K. 2017. Aerial and underwater sound of unmanned aerial vehicles (UAV). J. Unmanned Veh. Syst. 5: 92-101.

Ezat, M.A., Fritsch, C.J., and Downs, C.T. 2018. Use of an unmanned aerial vehicle (drone) to survey Nile crocodile populations: A case study at Lake Nyamithi, Ndumo game reserve, South Africa. Biol. Conserv. 223: 76-81.

Ferguson, M.C., Angliss, R.P., Kennedy, A., Lynch, B., Willoughby, A., Helker, V., Brower, A.A., and Clarke, J.T. 2018. Performance of manned and unmanned aerial surveys to collect visual data and imagery for estimating Arctic cetacean density and associated uncertainty. J. Unmanned Veh. Syst. 6: 128-154.

Fettermann, T., Fiori, L., Bader, M., Doshi, A., Breen, D., Stockin, K.A., and Bollard, B. 2019. Behaviour reactions of bottlenose dolphins (Tursiops truncatus) to multirotor unmanned aerial vehicles (UAVs). Sci. Rep. 9: 8558.

Fiori, L., Doshi, A., Martinez, E., Orams, M.B., and Bollard-Breen, B. 2017. The use of unmanned aerial systems in marine mammal research. Remote Sens. 9: 543.

Francis, R.J., Lyons, M.B., Kingsford, R.T., and Brandis, K.J. 2020. Counting mixed breeding aggregations of animal species using drones: Lessons from waterbirds on semi-automation. Remote Sens. 12: 1185.

Frixione, M.G., Gómez García, M.J., and Gauger, M.F.W. 2020. Drone imaging of elasmobranchs: Whale sharks and golden cownose rays co-occurrence in a zooplankton hot-spot in southwestern Sea of Cortez. Food Webs, 24: e00155. 
Table A1. (continued).

Fu, Y., Kinniry, M., and Kloepper, L.N. 2018. The Chirocopter: A UAV for recording sound and video of bats at altitude. Methods Ecol. Evol. 9: 1531-1535.

Gallagher, A.J., Papastamatiou, Y.P., and Barnett, A. 2018. Apex predatory sharks and crocodiles simultaneously scavenge a whale carcass. J. Ethol. 36: 205-209.

Gardner, S., Leroi, D., and Perryman, W. 2010. A penguin population polar express: NOAA's quest to count penguin breeds speeds up with a VTOL UAS. Unmanned Syst. 29: 30-35.

Gentle, M., Finch, N., Speed, J., and Pople, A. 2018. A comparison of unmanned aerial vehicles (drones) and manned helicopters for monitoring macropod populations. Wildl. Res. 45: 586-594.

Geoghegan, J.L., Pirotta, V., Harvey, E., Smith, A., Buchmann, J.P., Ostrowski, M., Eden, J., Harcourt, R., and Holmes, E.C. 2018. Virological sampling of inaccessible wildlife with drones. Viruses, 10: 300.

Giles, A.B., Butcher, P.A., Colefax, A.P., Pagendam, D.E., Mayjor, M., and Kelaher, B.P. 2021. Responses of bottlenose dolphins (Tursiops spp.) to small drones. Aquat. Conserv. 31: 677-684.

Goebel, M.E., Perryman, W.L., Hinke, J.T., Krause, D.J., Hann, N.A., Gardner, S., and LeRoi, D.J. 2015. A small unmanned aerial system for estimating abundance and size of Antarctic predators. Polar Biol. 38: 619-630.

Gonzalez, F., and Johnson, S. 2017. Standard operating procedures for UAV or drone-based monitoring of wildlife. Proceedings of the UAS4RS 2017 (Unmanned Aircraft Systems for Remote Sensing) Conference. (Ed. D. Turner) University of Tasmania, Hobart, Australia. pp. 1-7.

Gonzalez, L.F., Montes, G.A., Puig, E., Johnson, S., Mengersen, K., and Gaston, K.J. 2016. Unmanned aerial vehicles (UAVs) and artificial intelligence revolutionizing wildlife monitoring and conservation. Sensors, $16: 97$.

Gooday, O.J., Key, N., Goldstien, S., and Zawar-Reza, P. 2018. An assessment of thermal-image acquisition with an unmanned aerial vehicle (UAV) for direct counts of coastal marine mammals ashore. J. Unmanned Veh. Syst. 6: $100-108$.

Gorkin, R., Adams, K., Berryman, M.J., Aubin, S., Li, W., Davis, A.R., and Barthelemy, J. 2020. Sharkeye: Real-time autonomous personal shark alerting via aerial surveillance. Drones, 4: 18.

Gray, P.C., Fleishman, A.B., Klein, D.J., McKown, M.W., Bézy, V.S., Lohmann, K.J., and Johnston, D.W. 2019. A convolutional neural network for detecting sea turtles in drone imagery. Methods Ecol. Evol. 10: 345-355.

Grenzdörffer, G.J. 2013. UAS-based automatic bird count of a common gull colony. In International Archives of the Photogrammetry, Remote Sensing and Spatial Information Sciences, Volume XL-1/W2. Edited by G. Grenzdörffer and R. Bill. International Society for Photogrammetry and Remote Sensing, Leibniz University of Hannover, Hanover, Germany. pp. 169-174.

Guo, X., Shao, Q., Li, Y., Wang, Y., Wang, D., Liu, J., Fan, J., and Yang, F. 2018. Application of UAV remote sensing for a population census of large wild herbivores - Taking the Headwater Region of the Yellow River as an example. Remote Sens. 10: 1041.

Haalck, L., Mangan, M., Webb, B., and Risse, B. 2020. Towards image-based animal tracking in natural environments using a freely moving camera. J. Neurosci. Methods, 330: 108455.

Hahn, N., Mwakatobe, A., Konuche, J., de Souza, N., Keyyu, J., Goss, M., Chang’a, A., Palminteri, S., Dinerstein, E., and Olson, D. 2017. Unmanned aerial vehicles mitigate human-elephant conflict on the borders of Tanzanian Parks: a case study. Oryx, 51: 513-516.

Hamilton, G., Corcoran, E., Denman, S., Hennekam, M.E., and Koh, L.P. 2020. When you can't see the koalas for the trees: using drones and machine learning in complex environments. Biol. Cons. 247: 108598.

Han, Y., Yoo, S.H., and Kwon, O. 2017. Possibility of applying unmanned aerial vehicle (UAV) and mapping software for the monitoring of waterbirds and their habitats. J. Ecol. Environ. 41: 21.

Harris, C.M., Herata, H., and Hertel, F. 2019. Environmental guidelines for operation of remotely piloted aircraft systems (RPAS): Experience from Antarctica. Biol. Cons. 236: 521-531.

He, G., Yang, H., Pan, R., Sun, Y., Zheng, P., Wang, J., Jin, X., Zhang, J., Li, B., and Guo, S. 2020. Using unmanned aerial vehicles with thermal-image acquisition cameras for animal surveys: A case study on the Sichuan snubnosed monkey in the Qinling Mountains. Integr. Zool. 15: 79-86.

Hensel, E., Wenclawski, S., and Layman, C.A. 2018. Using a small, consumer-grade drone to identify and count marine megafauna in shallow habitats. Lat. Am. J. Aquat. Res. 46: 1025-1033.

Hodgson, A., Kelly, N., and Peel, D. 2013. Unmanned aerial vehicles (UAVs) for surveying marine fauna: A dugong case study. PLoS ONE, 8: e79556.

Hodgson, A., Peel, D., and Kelly, N. 2017. Unmanned aerial vehicles for surveying marine fauna: Assessing detection probability. Ecol. Appl. 27: 1253-1267.

Hodgson, A.J., Noad, M., Marsh, H., Lanyon, J., and Kniest, E. 2010. Using unmanned aerial vehicles for surveys of marine mammals in Australia: Test of concept. Final report to the Australian Marine Mammal Centre.

Hodgson, J., Baylis, S., Mott, R., Herrod, A., and Clarke, R.H. 2016. Precision wildlife monitoring using unmanned aerial vehicles. Sci. Rep. 6: 22574.

Hodgson, J.C., and Koh, L.P. 2016. Best practice for minimising unmanned aerial vehicle disturbance to wildlife in biological field research. Curr. Biol. 26: R404-R405.

Hodgson, J.C., Holman, D., Terauds, A., Koh, L.P., and Goldsworthy, S.D. 2020. Rapid condition monitoring of an endangered marine vertebrate using precise, non-invasive morphometrics. Biol. Conserv. 242: 108402.

Hong, S., Han, Y., Kim, S., Lee, A., and Kim, G. 2019. Application of deep-learning methods to bird detection using unmanned aerial vehicle imagery. Sensors, 19: 1651. 
Table A1. (continued).

Horton, T.W., Hauser, N., Cassel, S., Klaus, K.F., Fettermann, T., and Key, N. 2019. Doctor Drone: Non-invasive measurement of humpback whale vital signs using unoccupied aerial system infrared thermography. Front. Mar. Sci. 6: 466.

Howard, C.Q., Hodgson, J.C., and Koh, L.P. 2018. Heart rate measurement of nesting birds using a microphone in a plastic egg. Proceedings of Acoustics 2018. Australian Acoustical Society, Australia.

Hyun, C., Park, M., and Lee, W.Y. 2020. Remotely piloted aircraft system (RPAS)-based wildlife detection: A review and case studies in maritime Antarctica. Animals, 10: 2387.

Inman, V.L., Kingsford, R.T., Chase, M.J., and Leggett, K.E.A. 2019. Drone-based effective counting and ageing of hippopotamus (Hippopotamus amphibius) in the Okavango Delta in Botswana. PLoS ONE, 14: e0219652.

Inoue, S., Yamamoto, S., Ringhofer, M., Mendonça, R.S., Pereira, C., and Hirata, S. 2019. Spatial positioning of individuals in a group of feral horses: A case study using drone technology. Mamm. Res. 64: 249-259.

Ireland, A.W., Palandro, D.A., Garas, V.Y., Woods, R.W., Davi, R.A., Butler, J.D., Gibbens, D.M., and Gibbens, J.S. 2019. Testing unmanned aerial systems for monitoring wildlife at night. Wildl. Soc. Bull. 43: 182-190.

Israel, M. 2011. A UAV-based roe deer fawn detection system. Int. Arch. Photogramm. Remote Sens. Spatial Inf. Sci. XXXVIII-1: 51-55.

Jarrett, D., Calladine, J., Cotton, A., Wilson, M.W., and Humphreys, E. 2020. Behavioural responses of non-breeding waterbirds to drone approach are associated with flock size and habitat. Bird Study, 67: 190-196.

Jech, J.M., Johnson, J.J., Lutcavage, M., Vanderlaan, A.S.M., Rzhanov, Y., and LeRoi, D. 2020. Measurements of juvenile Atlantic bluefin tuna (Thunnus thynnus) size using an unmanned aerial system. J. Unmanned Veh. Syst. 8: $140-160$.

Johnston, D.W. 2019. Unoccupied aircraft systems in marine science and conservation. Ann. Rev. Mar. Sci. 11: 439-463.

Johnston, D.W., Dale, J., Murray, K.T., Josephson, E., Newton, E., and Wood, S. 2017. Comparing occupied and unoccupied aircraft surveys of wildlife populations: Assessing the gray seal (Halichoerus grypus) breeding colony on Muskeget Island, USA. J. Unmanned Veh. Syst. 5: 178-191.

Jones, G.P., Pearlstine, L.G., and Percival, H.F. 2006. An assessment of small unmanned aerial vehicles for wildlife research. Wildl. Soc. Bull. 34: 750-758.

Jones, G.P. 2003. Feasibility of using small unmanned aerial vehicles for wildlife research. $\mathrm{PhD}$ thesis, University of Florida, Gainesville, Florida.

Joyce, K.E., Duce, S., Leahy, S.M., Leon, J., and Maier, S.W. 2019. Principles and practice of acquiring drone-based image data in marine environments. Mar. Freshw. Res. 70: 952-963.

Junda, J.H., Greene, E., Zazelenchuk, D., and Bird, D.M. 2016. Nest defense behaviour of four raptor species (osprey, bald eagle, ferruginous hawk, and red-tailed hawk) to a novel aerial intruder - A small rotary-winged drone. J. Unmanned Veh. Syst. 4: 217-227.

Junda, J., Greene, E., and Bird, D.M. 2015. Proper flight technique for using a small rotary-winged drone aircraft to safely, quickly, and accurately survey raptor nests. J. Unmanned Veh. Syst. 3: 222-236.

Kays, R., Sheppard, J., Mclean, K., Welch, C., Paunescu, C., Wang, V., Kravit, G., and Crofoot, M. 2019. Hot monkey, cold reality: Surveying rainforest canopy mammals using drone-mounted thermal infrared sensors. Int. J. Remote Sens. 40: 407-419.

Kelaher, B.P., Peddemors, V.M., Hoade, B., Colefax, A.P., and Butcher, P.A. 2020. Comparison of sampling precision for nearshore marine wildlife using unmanned and manned aerial surveys. J. Unmanned Veh. Syst. 8: 30-43.

Kelaher, B.P., Colefax, A.P., Tagliafico, A., Bishop, M.J., Giles, A., and Butcher, P.A. 2020. Assessing variation in assemblages of large marine fauna off ocean beaches using drones. Mar. Freshw. Res. 71: 68-77.

Kellenberger, B., Marcos, D., and Tuia, D. 2018. Detecting mammals in UAV images: Best practices to address a substantially imbalanced dataset with deep learning. Remote Sens. Environ. 216: 139-153.

Korczak-Abshire, M., Kidawa, A., Zmarz, A., Storvold, R., Karlsen, S.R., Rodzewicz, M., Chwedorzewska, K., and Znój, A. 2016. Preliminary study on nesting Adélie penguins disturbance by unmanned aerial vehicles. CCAMLR Sci. 23: 1-16.

King, L.M. 2014. Will drones revolutionise ecotourism? J. Ecotourism, 13: 85-92.

Kiszka, J.J., Mourier, J., Gastrich, K., and Heithaus, M.R. 2016. Using unmanned aerial vehicles (UAVs) to investigate shark and ray densities in a shallow coral lagoon. Mar. Ecol. Prog. Ser. 560: 237-242.

Kloepper, L.N., and Kinniry, M. 2018. Recording animal vocalizations from a UAV: Bat echolocation during roost re-entry. Sci. Rep. 8: 7779.

Koh, L.P., and Wich, S.A. 2012. Dawn of drone ecology: low-cost autonomous aerial vehicles for conservation. Trop. Conserv. Sci. 5: 121-132.

Korczak-Abshire, M., Zmarz, A., Rodzewicz, M., Kycko, M., Karsznia, I., and Chwedorzewska, K.J. 2019. Study of fauna population changes on Penguin Island and Turret Point Oasis (King George Island, Antarctica) using an unmanned aerial vehicle. Polar Biol. 42: 217-224.

Koski, W.R., Allen, T., Ireland, D., Buck, G., Smith, P.R., Macrander, A.M., Halick, M.A., Rushing, C., Sliwa, D.J., and McDonald, T.L. 2009. Evaluation of an unmanned airborne system for monitoring marine mammals. Aquat. Mamm. 35: 347-357. 
Table A1. (continued).

Koski, W.R., Gamage, G., Davis, A.R., Mathews, T., LeBlanc, B., and Ferguson, S.H. 2015. Evaluation of UAS for photographic re-identification of bowhead whales, Balaena mysticetus. J. Unmanned Veh. Syst. 3: 22-29.

Koski, W.R., Thomas, T.A., Funk, D.W., and Macrander, A.M. 2013. Marine mammal sightings by analysts of digital imagery versus aerial surveyors: A preliminary comparison. J. Unmanned Veh. Syst. 1: 25-40.

Krause, D.J., Hinke, J.T., Perryman, W.L., Goebel, M.E., and LeRoi, D.J. 2017. An accurate and adaptable photogrammetric approach for estimating the mass and body condition of pinnipeds using an unmanned aerial system. PLoS ONE, 12: e0187465.

Lachman, D., Conway, C., Vierling, K., and Matthews, T. 2020. Drones provide a better method to find nests and estimate nest survival for colonial waterbirds: A demonstration with western grebes. Wetl. Ecol. Manag. 28: 837-845.

Lea, J.S.E., Daly, R., Leon, C., Daly, C., and Clarke, C. 2018. Life after death: Behaviour of multiple shark species scavenging a whale carcass. Mar. Freshw. Res. 70: 302e306.

Lee, W.Y., Park, M., and Hyun, C. 2019. Detection of two Arctic birds in Greenland and an endangered bird in Korea using RGB and thermal cameras with an unmanned aerial vehicle (UAV). PLoS ONE, 14: e0222088.

Liu, C.C., Chen, Y.H., and Wen, H.L. 2015. Supporting the annual international black-faced spoonbill census with a low-cost unmanned aerial vehicle. Ecol. Inform. 30: 170-178.

López, J.J., and Mulero-Pázmány, M. 2019. Drones for conservation in protected areas: Present and future. Drones, 3 : 10.

Lyons, M.B., Brandis, K.J., Murray, N.J., Wilshire, J.H., McCann, J.A., Kingsford, R.T., and Callaghan, C.T. 2019. Monitoring large and complex wildlife aggregations with drones. Methods Ecol. Evol. 10: 1024-1035.

Lyons, M., Brandis, K., Callaghan, C., McCann, J., Mills, C., Ryall, S., and Kingsford, R. 2018. Bird interactions with drones, from individuals to large colonies. Aust. Field Ornithol. 35: 51-56.

Lyons, M., Brandis, K., Wilshire, J., Murray, N., McCann, J., Kingsford, R., and Callaghan, C. 2019. A protocol for using drones to assist monitoring of large breeding bird colonies. EcoEvoRxiv.

Magness, D.R., Eskelin, T., Laker, M., and Renner, H.M. 2019. Evaluation of small unmanned aerial systems as a census tool for Aleutian tern Onychoprion aleuticus colonies. Mar. Ornithol. 47: 11-16.

Mapes, K.L., Pricope, N.G., Baxley, J.B., Schaale, L.E., and Danner, R.M. 2020. Thermal imaging of beach-nesting bird habitat with unmanned aerial vehicles: Considerations for reducing disturbance and enhanced image accuracy. Drones, 4: 12.

Marine Mammal Commission. 2016. Development and use of UASs by the National Marine Fisheries Service for surveying marine mammals. Marine Mammal Commission, Bethesda, Maryland, USA.

Martin, J., Edwards, H.H., Burgess, M.A., Percival, H.F., Fagan, D.E., Gardner, B.E., Ortega-Ortiz, J.G., Ifju, P.G., Evers, B.S., and Rambo, T.J. 2012. Estimating distribution of hidden objects with drones: From tennis balls to manatees. PLoS ONE, 7: e38882.

McCarthy, E.D. 2020. Investigating the use of drone-acquired thermal imagery as an effective new tool to inform the management and conservation of flying-fox colonies. Masters thesis, Western Sydney University, Australia.

McClelland, G.T.W., Bond, A.L., Sardana, A., and Glass, T. 2016. Rapid population estimate of a surface-nesting seabird on a remote island using a low-cost unmanned aerial vehicle. Mar. Ornithol. 44: 215-220.

McEvoy, J.F., Hall, G.P., and McDonald, P.G. 2016. Evaluation of unmanned aerial vehicle shape, flight path and camera type for waterfowl surveys: Disturbance effects and species recognition. PeerJ, 4: e1831.

McIntosh, R.R., Holmberg, R., and Dann, P. 2018. Looking without landing - Using remote piloted aircraft to monitor fur seal populations without disturbance. Front. Mar. Sci. 5: 202.

McKellar, A.E., Shephard, N.G., and Chabot, D. 2021. Dual visible-thermal camera approach facilitates drone surveys of colonial marshbirds. Remote Sens. Ecol. Cons. 7: 214-226.

Mesquita, G.P., Rodríguez-Teijeiro, J.D., Wich, S.A., and Mulero-Pázmány, M. 2020. Measuring disturbance at swift breeding colonies due to the visual aspects of a drone: A quasi-experiment study. Curr. Zool. 67: 157-163.

Moreland, E.E., Cameron, M.F., Angliss, R.P., and Boveng, P.L. 2015. Evaluation of a ship-based unoccupied aircraft system (UAS) for surveys of spotted and ribbon seals in the Bering Sea pack ice. J. Unmanned Veh. Syst. 3: 114-122.

Mulero-Pázmány, M., Jenni-Eiermann, S., Strebel, N., Sattler, T., Negro, J.J., and Tablado, Z. 2017. Unmanned aircraft systems as a new source of disturbance for wildlife: a systematic review. PLoS ONE, 12: e0178448.

Mulero-Pázmány, M., Stolper, R., van Essen, L.D., Negro, J.J., and Sassen, T. 2014. Remotely piloted aircraft systems as a rhinoceros anti-poaching tool in Africa. PLoS ONE, 9: e83873.

Mustafa, O., Barbosa, A., Krause, D.J., Peters, H., Vieira, G., and Rümmler, M. 2018. State of knowledge: Antarctic wildlife response to unmanned aerial systems. Polar Biol. 41: 2387-2398.

Mustafa, O., Braun, C., Esefeld, J., Knetsch, S., Maercker, J., Pfeifer, C., and Rümmler, M. 2019. Detecting Antarctic seals and flying seabirds by UAV. In Annals of the Photogrammetry, Remote Sensing and Spatial Information Sciences, Volume IV-2/W5 2019. Edited by G. Vosselman, S.J. Oude Elberink, and M.Y. Yang. International Society for Photogrammetry and Remote Sensing, Leibniz University of Hannover, Hanover, Germany. pp. 141-148.

Mustafa, O., Esefeld, J., Grämer, H., Maercker, J., Rümmler, M., Senf, M., Pfeifer, C., and Peter, H. 2017. Monitoring penguin colonies in the Antarctic using remote sensing data. German Environment Agency, Dessau-Roßlau, Germany.

Nakajima, K., Seo, K., Inoue, M., Shiotsuki, T., and Koizumi, H. 2019. Development of drone systems for prevention of bird damage. J. Jap. Soc. Agric. Mach. Food Engineers, 81: 112-119. 
Table A1. (continued).

Nelson, T.M., Wallen, M.M., Bunce, M., Oskam, C.L., Lima, N., Clayton, L., and Mann, J. 2019. Detecting respiratory bacterial communities of wild dolphins: Implications for animal health. Mar. Ecol. Prog. Ser. 622: 203-217.

Oliveira-da-Costa, M., Marmontel, M., Da-Rosa, D., Coelho, A., Wich, S., Mosquera-Guerra, F., and Trujillo, F. 2020. Effectiveness of unmanned aerial vehicles to detect Amazon dolphins. Oryx, 54: 696-698.

Oosthuizen, W.C., Krüger, L., Jouanneau, W., and Lowther, A.D. 2020. Unmanned aerial vehicle (UAV) survey of the Antarctic shag (Leucocarbo bransfieldensis) breeding colony at Harmony Point, Nelson Island, South Shetland Islands. Polar Biol. 43: 187-191.

Parker G.C., and Rexer-Huber K. 2020. Drone-based Salvin's albatross population assessment: feasibility at the Bounty Islands. Report to the Department of Conservation, Marine Species and Threats. Parker Conservation, Dunedin, New Zealand.

Perryman, W., Goebel, M.E., Ash, N., Leroi, D., and Gardner, S. 2014. Small unmanned aerial systems for estimating abundance of krill-dependent predators: A feasibility study with preliminary results. In AMLR 2010-2011 field season report. Edited by J.G. Walsh. U.S. Department of Commerce, National Marine Fisheries Service, La Jolla, California. pp. 64-73.

Pfeifer, C., Barbosa, A., Mustafa, O., Peter, H., Rümmler, M., and Brenning, A. 2019. Using fixed-wing UAV for detecting and mapping the distribution and abundance of penguins on the South Shetlands Islands, Antarctica. Drones, 3: 39.

Pirotta, V., Smith, A., Ostrowski, M., Russell, D., Jonsen, I.D., Grech, A., and Harcourt, R. 2017. An economical custom-built drone for assessing whale health. Front. Mar. Sci. 4: 425.

Pomeroy, P., Connor, L.O., and Davies, P. 2015. Assessing use of and reaction to unmanned aerial systems in gray and harbor seals during breeding and molt in the UK. J. Unmanned Veh. Syst. 3: 102-113.

Porter, M.E., Ruddy, B.T., and Kajiura, S.M. 2020. Volitional swimming kinematics of blacktip sharks, Carcharhinus limbatus, in the wild. Drones, 4: 78.

Potapov, E.R., Utekhina, I.G., McGrady, M.J., and Rimlinger, D. 2013. Usage of UAV for surveying Steller's sea eagle nests. Raptors Conserv. 27: 253-260.

Racanelli, V., Bartolozzi, S., Sorbetti Guerri, E., and Sorbetti Guerri, F. 2018. Use of remotely piloted aerial systems (R.P.A.S.) for wildlife monitoring. Proceedings of the 17th International Scientific Conference - Engineering for Rural Development, 23-25 May 2018, Jelgava, Latvia. pp. 1611-1617.

Radiansyah, S., Kusrini, M.D., and Prasetyo, L.B. 2017. Quadcopter applications for wildlife monitoring. IOP Conf. Ser. Earth and Environ. Sci. 54: 012066.

Ramos, E.A., Maloney, B., Magnasco, M.O., and Reiss, D. 2018. Bottlenose dolphins and Antillean manatees respond to small multi-rotor unmanned aerial systems. Front. Mar. Sci. 5: 316.

Raoult, V., Colefax, A.P., Allan, B.M., Cagnazzi, D., Castelblanco-Martínez, N., Ierodiaconou, D., Johnston, D.W., Landeo-Yauri, S., Lyons, M., Pirotta, V., Schofield, G., and Butcher, P.A. 2020. Operational protocols for the use of drones in marine animal research. Drones, 4: 64.

Raoult, V., Tosetto, L., and Williamson, J.E. 2018. Drone-based high-resolution tracking of aquatic vertebrates. Drones, 2: 37.

Ratcliffe, N., Guihen, D., Robst, J., Crofts, S., Stanworth, A., and Enderlein, P. 2015. A protocol for the aerial survey of penguin colonies using UAVs. J. Unmanned Veh. Syst. 3: 95-101.

Raudino, H.C., Tyne, J.A., Smith, A., Ottewell, K., McArthur, S., Kopps, A.M., Chabanne, D., Harcourt, R.G., Pirotta, V., and Waples, K. 2019. Challenges of collecting blow from small cetaceans. Ecosphere, 10: e02901.

Rebolo-Ifrán, N., Graña Grilli, M., and Lambertucci, S.A. 2019. Drones as a threat to wildlife: YouTube complements science in providing evidence about their effect. Environ. Conserv. 46: 205-210.

Rees, A.F., Avens, L., Ballorain, K., Bevan, E., Broderick, A.C., Carthy, R.R., Christianen, M.J.A., Duclos, G., Heithaus, M.R., Johnston, D.W., Mangel, J.C., Paladino, F., Pendoley, K., Reina, R.D., Robinson, N.J., Ryan, R., Sykora-Bodie, S.T., Tilley, D., Varela, M.R., Whitman, E.R., Whittock, P.A., Wibbels, T., and Godley, B.J. 2018. The potential of unmanned aerial systems for sea turtle research and conservation: A review and future directions. Endanger. Species Res. 35: 81-100.

Rexer-Huber, K., and Parker, G.C. 2020. Bounty Islands drone trials: Feasibility for population assessment of NZ fur seal. Final report to the Conservation Services Programme, Department of Conservation. Parker Conservation, Dunedin, New Zealand.

Rieucau, G., Kiszka, J.J., Castillo, J.C., Mourier, J., Boswell, K.M., and Heithaus, M.R. 2018. Using unmanned aerial vehicle (UAV) surveys and image analysis in the study of large surface-associated marine species: A case study on reef sharks Carcharhinus melanopterus shoaling behaviour. J. Fish Biol. 93: 119-127.

Rischette, A.C., Hovick, T.J., Elmore, R.D., and Geaumont, B.A. 2020. Use of small unmanned aerial systems for sharp-tailed grouse lek surveys. Wildl. Biol. 2020: 00679.

Rümmler, M. 2017. Penguins and drones: impacts of overflights by a micro UAV on two Pygoscelis penguin species. Masters thesis, Friedrich Schiller University Jena, Germany.

Rümmler, M., Mustafa, O., Maercker, J., Peter, H., and Esefeld, J. 2016. Measuring the influence of unmanned aerial vehicles on Adélie penguins. Polar Biol. 39: 1329-1334.

Rümmler, M., Mustafa, O., Maercker, J., Peter, H., and Esefeld, J. 2018. Sensitivity of Adélie and gentoo penguins to various flight activities of a micro UAV. Polar Biol. 41: 2481-2493. 
Table A1. (continued).

Rush, G.P., Clarke, L.E., Stone, M., and Wood, M.J. 2018. Can drones count gulls? Minimal disturbance and semiautomated image processing with an unmanned aerial vehicle for colony-nesting seabirds. Ecol. Evol. 8: 12322-12334.

Saqib, M., Daud Khan, S., Sharma, N., Scully-Power, P., Butcher, P., Colefax, A., and Blumenstein, M. 2018. Real-time drone surveillance and population estimation of marine animals from aerial imagery. 2018 International Conference on Image and Vision Computing New Zealand, 19-21 November 2018, Auckland, New Zealand.

Sardà-Palomera, F., Bota, G., Padilla, N., Brotons, L., and Sardà, F. 2017. Unmanned aircraft systems to unravel spatial and temporal factors affecting dynamics of colony formation and nesting success in birds. J. Avian Biol. 48: $1273-1280$

Sardà-Palomera, F., Bota, G., Viñolo, C., Pallarés, O., Sazatornil, V., Brotons, L., Gomáriz, S., and Sardà, F. 2012. Fine-scale bird monitoring from light unmanned aircraft systems. Ibis, 154: 177-183.

Schofield, G., Esteban, N., Katselidis, K.A., and Hays, G.C. 2019. Drones for research on sea turtles and other marine vertebrates - A review. Biol. Conserv. 238: 108214

Schofield, G., Katselidis, K.A., Lilley, M.K.S., Reina, R.D., and Hays, G.C. 2017. Detecting elusive aspects of wildlife ecology using drones: New insights on the mating dynamics and operational sex ratios of sea turtles. Funct. Ecol. 31: 2310-2319.

Schroeder, N.M., Panebianco, A., Gonzalez Musso, R., and Carmanchahi, P. 2020. An experimental approach to evaluate the potential of drones in terrestrial mammal research: a gregarious ungulate as a study model. R. Soc. Open Sci. 7: 191482.

Scobie, C.A., and Hugenholtz, C.H. 2016. Wildlife monitoring with unmanned aerial vehicles: Quantifying distance to auditory detection. Wildl. Soc. Bull. 40: 781-785.

Selby, W., Corke, P., and Rus, D. 2011. Autonomous aerial navigation and tracking of marine mammals. Proceedings of the 2011 Australasian Conference on Robotics and Automation, 7-9 December 2011, Melbourne, Australia. pp. 1-7.

Semel, B.P., Karpantya, S.M., Vololonirina, F.F., and Rakotonanahary, A.N. 2020. Eyes in the sky: Assessing the feasibility of low-cost, ready-to-use unmanned aerial vehicles to monitor primate populations directly. Folia Primatol. 91: 69-82.

Seymour, A., Dale, J., Hammill, M., Halpin, P.N., and Johnston, D.W. 2017. Automated detection and enumeration of marine wildlife using unmanned aircraft systems (UAS) and thermal imagery. Sci. Rep. 7: 45127.

Smit, R. 2016. Automatic animal detection using unmanned aerial vehicles in natural environments. Master's thesis, University of Groningen, The Netherlands.

Smith, C.E., Sykora-Bodie, S.T., Bloodworth, B., Pack, S.M., Spradlin, T.R., and LeBoeuf, N.R. 2016. Assessment of known impacts of unmanned aerial systems (UAS) on marine mammals: Data gaps and recommendations for researchers in the United States. J. Unmanned Veh. Syst. 1: 31-44.

Sorrell, K.J., Clarke, R.H., Holmberg, R., and McIntosh, R.R. 2019. Remotely piloted aircraft improve precision of capture-mark-resight population estimates of Australian fur seals. Ecosphere, 10: e02812.

Spaan, D., Burke, C., McAree, O., Aureli, F., Rangel-Rivera, C.E., Hutschenreiter, A., Longmore, S.N., McWhirter, P.R., and Wich, S.A. 2019. Thermal infrared imaging from drones offers a major advance for spider monkey surveys. Drones, 3: 34.

Su, X., Dong, S., Liu, S., Cracknell, A.P., Zhang, Y., Wang, X., and Liu, G. 2018. Using an unmanned aerial vehicle (UAV) to study wild yak in the highest desert in the world. Int. J. Remote Sens. 39: 5490-5503.

Sweeney, K.L., Helker, V.T., Perryman, W.L., LeRoi, D.J., Fritz, L.W., Gelatt, T.S., and Angliss, R.P. 2016. Flying beneath the clouds at the edge of the world: Using a hexacopter to supplement abundance surveys of Steller sea lions (Eumetopias jubatus) in Alaska. J. Unmanned Veh. Syst. 4: 70-81.

Sykora-Bodie, S.T., Bezy, V., Johnston, D.W., Newton, E., and Lohmann, K.J. 2017. Quantifying nearshore sea turtle densities: Applications of unmanned aerial systems for population assessments. Sci. Rep. 7: 17690.

Thapa, G.J., Thapa, K., Thapa, R., Jnawali, S.R., Wich, S.A., Poudyal, L.P., and Karki, S. 2018. Counting crocodiles from the sky: monitoring the critically endangered gharial (Gavialis gangeticus) population with an unmanned aerial vehicle (UAV). J. Unmanned Veh. Syst. 6: 71-82.

Thompson, T.R. 2018. Using remotely piloted aircraft and infrared technology to detect and monitor greater sage-grouse. Masters thesis, Utah State University, Logan, Utah.

Torres, L.G., Nieukirk, S.L., Lemos, L., and Chandler, T.E. 2018. Drone up! Quantifying whale behavior from a new perspective improves observational capacity. Front. Mar. Sci. 5: 319.

Tucker, J.P., Vercoe, B., Santos, I.R., Dujmovic, M., and Butcher, P.A. 2019. Whale carcass scavenging by sharks. Global Ecol. Conserv. 19: e00655.

Valle, R.G., and Scarton, F. 2018. Uso dei droni nel censimento degli uccelli acquatici nidificanti nel Nord Adriatico. Boll. Mus. Stor. Nat. Venezia, 69: 69-75.

Valle, R.G., and Scarton, F. 2019. Effectiveness, efficiency, and safety of censusing Eurasian oystercatchers Haematopus ostralegus by unmanned aircraft. Mar. Ornithol. 47: 87-93.

Valle, R.G., and Scarton, F. 2020. Drones improve effectiveness and reduce disturbance of censusing common redshanks Tringa totanus breeding on salt marshes. Ardea, 107: 275-282. 
Table A1. (concluded).

van Gemert, J.C., Verschoor, C.R., Mettes, P., Epema, K., Koh, L.P., and Wich, S. 2015. Nature conservation drones for automatic localization and counting of animals. In Computer Vision - European Conference on Computer Vision Workshops. Lecture Notes in Computer Science. Edited by L. Agapito, M. Bronstein, and C. Rother. Springer, Cham, Switzerland. pp. 255-270.

Vas, E., Lescroël, A., Duriez, O., Boguszewski, G., and Grémillet, D. 2015. Approaching birds with drones: First experiments and ethical guidelines. Biol. Letters, 11: 20140754.

Verfuss, U.K., Aniceto, A.S., Harris, D.V., Gillespie, D., Fielding, S., Jiménez, G., Johnston, P., Sinclair, R.R., Sivertsen, A., Solbø, S.A., Storvold, R., Biuw, M., and Wyatt, R. 2019. A review of unmanned vehicles for the detection and monitoring of marine fauna. Mar. Pollut. Bull. 140: 17-29.

Vermeulen, C., Lejeune, P., Lisein, J., Sawadogo, P., and Bouche, P. 2013. Unmanned aerial survey of elephants. PLoS ONE, 8: e54700.

Wallace, P., Martin, R., and White, I. 2018. Keeping pace with technology: Drones, disturbance and policy deficiency. J. Environ. Plan. Manag. 61: 1271-1288.

Wandrie, L.J., Klug, P.E., and Clark, M.E. 2019. Evaluation of two unmanned aircraft systems as tools for protecting crops from blackbird damage. Crop Prot. 117: 15-19.

Wang, D., Shao, Q., and Yue, H. 2019. Surveying wild animals from satellites, manned aircraft and unmanned aerial systems (UASs): A review. Remote Sens. 11: 1308.

Warembourg, C., Berger-González, M., Alvarez, D., Sousa, F.M., Hernández, A.L., Roquel, P., Eyerman, J., Benner, M., and Dürr, S. 2020. Estimation of free-roaming domestic dog population size: Investigation of three methods including an unmanned aerial vehicle (UAV) based approach. PLoS ONE, 15: e0225022.

Watts, A.C., Perry, J.H., Smith, S.E., Burgess, M.A., Wilkinson, B.E., Szantoi, Z., Ifju, P.G., and Percival, H.F. 2010. Small unmanned aircraft systems for low-altitude aerial surveys. J. Wildl. Manag. 74: 1614-1619.

Weimerskirch, H., Prudor, A., and Schull, Q. 2018. Flights of drones over sub-Antarctic seabirds show species and status-specific behavioural and physiological responses. Polar Biol. 41: 259-266.

Weissensteiner, M.H., Poelstra, J.W., and Wolf, J.B.W. 2015. Low-budget ready-to-fly unmanned aerial vehicles: An effective tool for evaluating the nesting status of canopy-breeding bird species. J. Avian Biol. 46: 425-430.

Weston, M.A., O’Brien, C., Kostoglou, K.N., and Symonds, M.R.E. 2020. Escape responses of terrestrial and aquatic birds to drones: Towards a code of practice to minimize disturbance. J. Appl. Ecol. 57: 777-785.

Wilson, A.M., Barr, J., and Zagorski, M. 2017. The feasibility of counting songbirds using unmanned aerial vehicles. The Auk, 134: 350-362.

Witczuk, J., Pagacz, S., Zmarz, A., and Cypel, M. 2018. Exploring the feasibility of unmanned aerial vehicles and thermal imaging for ungulate surveys in forests - Preliminary results. Int. J. Remote Sens. 39: 5504-5521.

Witt, R.R., Beranek, C.T., Howell, L.G., Ryan, S.A., Clulow, J., Jordan, N.R., Denholm, B., and Roff, A. 2020. Real-time drone derived thermal imagery outperforms traditional survey methods for an arboreal forest mammal. PLoS ONE, 15: e0242204.

Wu, F., Zhu, W., Wu, B., and Zhao, X. 2019. Method of automatic counting of large herbivores from UAV images in the Source Region of Three Rivers. Acta Theriol. Sin. 39: 450.

Yang, F., Shao, Q., and Jiang, Z. 2019. A population census of large herbivores based on UAV and its effects on grazing pressure in the Yellow-River-Source National Park, China. Int. J. Environ. Res. Public Health, 16: 4402.

Zmarz, A., Rodzewicz, M., Dąbski, M., Karsznia, I., Korczak-Abshire, M., and Chwedorzewska, K.J. 2018. Application of UAV BVLOS remote sensing data for multi-faceted analysis of Antarctic ecosystem. Remote Sens. Environ. 217: $375-388$. 